


\title{
Análisis sociocrítico de la construcción identitaria: el caso del libro Lo que se canta en Costa Rica
}

Sociocritical analysis of the Identity construction: the case of the book Lo que se canta en Costa Rica

\author{
Jorge Eduardo Carmona Ruiz ${ }^{1}$ \\ Recibido: 16 /5/ 2016 / Aprobado: 1/11/2016
}

Resumen

\begin{abstract}
En este artículo se presenta un análisis basado en los enfoques de la musicología sistemática según Lehnhoff (2005) y la sociocrítica (Amoretti, 1995; Carvajal, 2013) de Cros (1986a), sobre las relaciones interdiscursivas e intertextuales entre un grupo de canciones con letra de poetas nativos de San Ramón de Alajuela, Costa Rica. Se llega a la conclusión de que su "visión de mundo" se basa en la imagen del "labriego sencillo", creada a partir de la letra del Himno Nacional, y en la influencia que ejerció en los poetas su origen ramonense[3].
\end{abstract}

Palabras clave: Análisis sociocrítico de canciones, Lo que se canta en Costa Rica, canciones costarricenses, poetas ramonenses, construcción identitaria.

\section{Abstract}

This article presents an analysis based on the approaches from the systematic musicology according to Lehnhoff (2005) and Cros (1986a) sociocritics (Amoretti, 1995; Carvajal, 2013) of the interdiscursive and intertextual relations within a group of songs and poetry from Costa Rican authors (born in San Ramón, Alajuela, Costa Rica). It concludes that the "world view" is based on the image of the "simple peasant", labriego sencillo, based on the lyrics from the Costa Rican National Anthem, and its influence on the poets from San Ramón[4].

Key words: Analysis sociocritic songs, Lo que se canta en Costa Rica, Costarrican songs, ramonenses poets, Identity construction.

\section{Introducción}

En 1933 apareció el libro Lo que se canta en Costa Rica, editado por José Daniel Zúñiga; el texto ha marcado a muchas generaciones de costarricenses (Ríos, 2013: 102). En este texto el autor recopiló las letras de una alta cantidad de canciones e himnos de varios países y de varias instituciones. Luego de su aparición, el libro fue imprimido once veces más hasta la muerte del autor en 1981. En la actualidad es posible encontrarlo en las librerías del país en impresiones recientes. En la última edición, el libro está dividido en cuatro secciones: la primera con doscientas cincuenta y seis canciones; la segunda, con dieciocho himnos; otra con cuarenta y un himnos oficiales y particulares; por último, una sección con setenta y cuatro himnos, marchas y otras canciones. Todas estas canciones se cantaban en las escuelas y colegios del país debido a que, desde su aparición ha sido utilizado como libro de texto en los programas de estudio en Música del Ministerio de Educación Pública (MEP) independientemente de los factores ideológicos que hayan guiado al MEP en las diferentes épocas y gobiernos. Factores ideológicos que, según Carmen Mauro (2016: contacto personal), han sido importantes en la consecución del liberalismo hasta hoy. Este libro contiene solamente las letras de las canciones, no así

\footnotetext{
${ }^{1}$ Pianista, profesor e investigador del Conservatorio de Música de la Sede de Occidente de la Universidad de Costa Rica. Correo electrónico: jorge.carmona@ucr.ac.cr
} 
su música, por lo que para las nuevas generaciones ha sido muy difícil conocer cómo sonaba la música, a causa de que cada vez se cantan menos y existen pocas grabaciones.

En 2004, el libro Época de oro de la canción escolar costarricense, editado por Juan Rafael Camacho y Juan Ernesto Quesada (Quesada y Camacho, 2004), vino a resolver, en gran parte, ese problema. Los investigadores se dieron a la tarea de poner en partitura ciento noventa y nueve de las canciones de Lo que se canta en Costa Rica. Esta investigación es la tesis de licenciatura que los autores presentaron en la Universidad Nacional. Luego se convirtió en libro y recibió el Premio Aquileo J. Echeverría al mejor libro en la categoría de "no ubicable" del año 2005; en el libro se incluyen varias canciones cuyas letras fueron escritas por autores originarios de la ciudad de San Ramón de Alajuela, reconocida como cuna de importantes poetas costarricenses (Rodríguez, inédito).

Así, el presente artículo tiene como objetivo general el estudio de las relaciones interdiscursivas e intertextuales entre letra y música en esas canciones con el fin de entender la visión de mundo que nos muestra el corpus estudiado. Para el logro de este objetivo esta investigación se ha basado en las teorías de la sociocrítica y la músicología sistemática.

\section{San Ramón, tierra de poetas}

En su artículo San Ramón tierra de poetas, el investigador Francisco Rodríguez (2014) describe cómo la ciudad, prácticamente desde su momento fundacional, se ha preocupado por brindar a sus habitantes un nivel educativo y cultural muy elevado. Es descrita en este trabajo como una "minúscula ciudad letrada", según el concepto aportado por Ángel Rama (Rodríguez, 2014: s.n.p.). Desde sus inicios, tuvo varias escuelas; incluso, en las épocas en que hubo poco apoyo estatal a la educación, en el pueblo se preocupó por crear escuelas privadas para mantener el nivel educativo (Rodríguez, 2014; Alpízar, 2015: 22s.)
Según Rodríguez (2014) apenas treinta y cinco años después de su fundación, en el año 1879 , una sociedad con cuarenta miembros funda la primera biblioteca pública. Dos años después, llega a la ciudad la primera imprenta, la que dio inicio a una larga historia de publicaciones periodísticas y literarias en el cantón. Tales medios, comenta Rodríguez (2014), "no solo eran concebidos como transmisores de información sino como agentes de desarrollo y difusión cultural" (s.n.p.) ya que:

Antes que al amarillismo y la banalidad, el periodismo ramonense desde finales del siglo XIX hasta la primera parte del siglo XX, apostó a la cultura letrada y, en su seno, a la literatura como modelos culturales que se debían defender y propagar.

(Rodríguez, 2014: s.n.p.)

A lo cual se le suma la existencia de dos personajes que marcaron el inicio de la historia de la comunidad y el imaginario ramonense como "ciudad letrada" o como "la ciudad de los poetas": Julián Volio Llorente (1827-1889) y Lisímaco Chavarría (1873-1913). El primero fue un intelectual, abogado y político que vivió algunos años en San Ramón en la segunda mitad del siglo XIX, que creó a su alrededor todo un círculo intelectual y cultural que perduró mucho tiempo luego de su partida de la ciudad. Incluso, fundó una academia de jurisprudencia reconocida por las autoridades nacionales. El segundo es uno de los poetas más importantes de la historia de la literatura costarricense. Su figura ha sido el emblema alrededor del que se ha construido, en gran parte, en el imaginario costarricense, la imagen de San Ramón como la "ciudad de los poetas"2.

A la pregunta ¿qué significaba ser poeta en San Ramón en la primera mitad del siglo XX? la historiadora Miriam Pineda responde:

\footnotetext{
${ }^{2}$ En la edición de las Obras completas de Lisímaco Chavarría, Francisco Rodríguez (Chavarría, 2013) realizó una exhaustiva y cuidada investigación sobre el poeta, su obra y su época.
} 
Significaba mucho. A inicios de siglo, todavía estaba vivo Lisímaco, se sentían halagados y apoyados por la Municipalidad, las escuelas, maestros y directores. Era una manera de vivir, aunque no remunerada económicamente. Eran reconocidos por el pueblo como personas valiosas... Era casi un privilegio dedicarse al arte, sobre todo porque, de la nada, hacían mucho." (Pineda, 2016: comunicación vía telefónica)

Afirma Pineda que, además de los poetas Lisímaco Chavarría, Félix Ángel Salas y Carlomagno Araya, había pintores y escultores como Lico Rodríguez. "Todos ellos surgieron porque había apoyo" sostiene.

Para resumir todo este fenómeno cultural, Francisco Rodríguez dice:

La existencia de una red de destacados intelectuales, la fundación de una Academia de Jurisprudencia, la fundación de una biblioteca destacada, el pronto desarrollo de la educación formal en todos sus niveles, la pronta aparición de la prensa y su labor fecunda y profusa, así como la organización de espacios para la cultura ilustrada, muestra una sociedad profundamente identificada con el desarrollo cultural, que incidió para que se generara en el siglo XIX una pequeña ciudad letrada en San Ramón y el establecimiento de un campo cultural diferenciado, a pesar de su lugar periférico respecto al josefino, que preparó el terreno para el surgimiento de la expresión letrada, con especial énfasis en la cultura literaria. (Rodríguez, 2014: s.n.p.)

Uno de los aspectos que resalta Pineda en sus declaraciones es el clima. San Ramón, hasta hace unos años, pasaba casi todo el año bajo una espesa neblina; era un clima sumamente húmedo y oscuro. Sin embargo, en los meses de marzo y abril, el clima cambiaba y se podía disfrutar mucho del sol, con atardeceres multicolores. Eso pudo haber influido en los poetas estudiados, ya que como afirma Pineda:
El clima incide en el pensamiento: la nostalgia, la pasividad que lleva a recordar lo que pasó, lo que pasa y lo que vendrá. En el verano hay viento, el frío, después de febrero, el cielo está despejado y se ven celajes. Es muy bonito. (Pineda, 2016: comunicación vía telefónica)

El pueblo de San Ramón vivió aislado del resto del país por mucho tiempo por la casi inexistencia de vías de comunicación. Su población, a pesar de su elevado nivel educativo y cultural, no era de una condición económica elevada; todo lo anterior marcará, de manera significativa, la visión de mundo que se analizará más adelante en este artículo.

\section{Acerca de las canciones}

Manuel Matarrita, en su libro sobre canciones populares costarricenses (Matarrita, 2009) se refiere a la clasificación realizada por Jaime Rico de las canciones costarricenses dividiéndolas en canciones folclóricas, canciones populares y canciones típicas. Matarrita añade dos categorías más con las que complementa el microcosmos del repertorio costarricense de canciones. Ellas son: canciones escolares y canciones artísticas. Las primeras son pequeñas obras creadas con fines didácticos y las segundas son compuestas de una manera más elaborada, pensadas, sobre todo, para recitales de cantantes líricos en una sala de conciertos (Matarrita, 2009: $\mathrm{x}$ ). Este último tipo de canción tiene su origen en las canciones artísticas europeas del siglo XIX: lied, en Alemania; chanson, en Francia; y tonadilla en España. (Matarrita, 2009: xiii) y han sido cultivadas en todos los ámbitos culturales, incluyendo toda la América Latina.

Desde finales del siglo XIX, los políticos liberales en Costa Rica, comprendieron que era por medio de la educación pública que se podía formar una identidad costarricense. Así, la literatura y otras formas culturales, insertas en el proceso educativo, en especial con la educación musical, se acercó a la sociedad costarricense a su ideología y la enseñanza de himnos y cantos patrióticos era 
esencial para conseguir ese fin (véanse Rojas y Ovares, 1995: 61-84; Carmona, 2001: 26; Carvajal, 2013: XVs.-82). Por eso, la enseñanza del canto fue parte fundamental de la enseñanza musical (Vargas: 2004: 211s.) $)^{3}$

María Isabel Carvajal asegura que la acción de cantar "en comunidad" potencia el mensaje que se quiere dar a través de la canción o himno y expresiones que están cargadas de elementos ideológicos. Según ella:

La puesta en marcha de un conglomerado de personas que en un momento determinado entonan un canto, repitiendo la misma letra, la misma música, el mismo mensaje, adquiere una fuerza ideológica que se multiplica aún más, ya que también alcanza o provoca sensaciones no solo en el que canta sino también en el que escucha. De esta forma, la acción generada por el canto de un himno puede incitar una reacción en cadena mucho mayor a la de un discurso carente de música. (Carvajal, 2013: 65)

La situación fue entendida y aprovechada por los diferentes gobiernos a los que les correspondió formar la nacionalidad costarricense y su identidad en el periodo entre siglos (Carvajal, 2011: 23). En especial, un texto al que se le agrega ritmo y melodía, es más fácil de memorizar. Por otro lado, el significado de las palabras se enriquece "debido al timbre usado y a la resonancia que se genera al emitir el sonido" (Carvajal, 2013: 2; 14; 65). Además, sostiene Carvajal, "estas manifestaciones simbólicas... tienen la particularidad de renovarse cada vez que son escuchadas, entonadas o ejecutadas por individuos que pertenecen a distintas generaciones" (Carvajal, 2013: 77) ${ }^{4}$. Es posible, entonces, imaginarse cuánto ha calado el canto de himnos y canciones patrióticas en el inconsciente de todas las generaciones que las han aprendido.

Por otra parte, Matarrita asegura que esta política educativa ha generado la creación de muchísimas canciones de todos los géneros que se enseñan en las escuelas y colegios del país. La mayoría han sido incluidas en Lo que se canta en Costa Rica y, por ende, en Época de oro de la canción escolar costarricense. Tal realidad ha provocado, como lo aclara Matarrita (2009: ix), la idea errónea de que todas esas canciones son cantos escolares. Pero muchas de ellas son, realmente, canciones artísticas de gran belleza estética y alto nivel de complejidad musical.

En el caso de las canciones estudiadas, todas están marcadas por el discurso que impuso en su época José María Zeledón, autor de la letra del Himno Nacional quien, tal como lo plantea María Amoretti:

... genera en su letra una serie de conceptos que se cristalizan en sintagmas fijos que adquieren una fuerza identificadora de tal envergadura, que seguirá rigiendo por mucho tiempo no solo nuestra producción ficcional, sino que además el discurso social sobre nuestra personalidad. (Amoretti, 1995: 63)

Y ese discurso que ha marcado la identidad costarricense, según Amoretti y otros, es el del "labriego sencillo", que describe al costarricense que es pobre, humilde, campesino que trabaja la tierra para lograr su sustento diario y sin pretensiones de atesorar ninguna fortuna. Con esta imagen, se creó la visión de mundo que ha caracterizado mucha de nuestra literatura y mucho de nuestro arte. La visión de país pobre en el que la felicidad de los

3 María Isabel Carvajal realiza un minucioso, amplio y agudo análisis de este fenómeno en su artículo Construcción imaginaria de Costa Rica en textos históricos e himnos (Carvajal, 2011)

4 Debe tomarse en cuenta lo que dice Dubois al respecto de las instituciones: “... aparecen como espacios de dominación y subordinación ideológica, no sólo (sic) por los discursos que difunden y los códigos que aplican, sino por su modo de recortar (décupage) la realidad de las prácticas sociales, por la manera en que fijan, en el terreno de la legitimidad, las condiciones de posibilidad y de ejercicio de estas prácticas”. (Dubois, 1979:p. 169 citado por Trottier: 1993: 39). 
hombres era ser pobres, viviendo en el campo o en la montaña, cultivando la tierra de esta madre patria, aislados de la sociedad pero en completa libertad sin ataduras ni siquiera con los bienes materiales. Un ambiente en el que se exalta la humildad como un valor cristiano (Amoretti, 1995: 65) y se condena la vida en ciudad por viciosa ${ }^{5}$. Amoretti, citando a Gallardo y Picado", concluye que "alrededor de la frase "sencillo labriego" se opera un circuito cerrado que realiza una dialéctica entre este monumento nacional llamado Himno y la producción ficcional" y hace una relación con el costumbrismo, "género inicial de nuestras letras" que crea "un planteamiento que acepte el efecto del "ser nacional" para apoyar la ideología imperante". Por eso, sostiene, se consolida la ideología dominante a través de esa imagen creada del "ser nacional" (Amoretti, 1995: 69).

Como se indicó anteriormente, el presente estudio es parte de los resultados obtenidos en el proyecto de investigación "Poetas ramonenses en el libro Época de oro de la canción escolar costarricense". Durante el proyecto se descubrió que veintiséis canciones de dicho libro tienen letra de autores ramonenses. Ellas tratan muy variados temas y además, cubren muchos géneros musicales de diverso nivel de dificultad técnica y musical; compuestas para distintos usos. Entre los poetas estudiados se cuenta a Carlomagno Araya, Lisímaco Chavarría, Marco Tulio Castro, Miguel Ángel Hidalgo, Alcides Prado, Edwin Salas y José Joaquín Salas Pérez. Los compositores de las canciones fueron José Joaquín Ureña, Tertuliano Mora,
José Daniel Zúñiga, Roberto Campabadal, Miguel Ángel Hidalgo y Alcides Prado.

Es posible clasificar las canciones en cinco grupos diferentes según su temática. Hay canciones infantiles, canciones que remiten a lugares idílicos ${ }^{7}$, algunas algunas tratan de diversos tipos de personajes, otras están dedicadas a la patria o a lugares específicos y, finalmente, canciones que están dedicadas a la madre.

De cada grupo se ha tomado, para su análisis, al menos una canción representativa al igual que de cada uno de los autores. Se tomó en cuenta, también, su presencia en el sistema escolar costarricense o popular del país. En ellas se buscó la relación entre letra y música (relación intertextual) y, luego, la presencia de diversos tipos de discursos que marcan la generalidad del corpus para concluir en la visión de mundo que representa.

\section{Relación intertextual entre letra y música}

La sociocrítica ${ }^{8}$, entre una numerosa serie de herramientas teórico-metodológicas importantes para los análisis literarios, ha propuesto tres conceptos que son básicos en la presente investigación. Se trata de los conceptos de intertextualidad, interdiscursividad y visión de mundo que son mecanismos productores de sentido con una orientación regida por una ideología dominante.

Edmond Cros (1986b: 78), dice que el intertexto es uno de los "centros de programación de la producción de sentido" del texto. El autor, que se

\footnotetext{
${ }^{5}$ Amoretti cita a Magón y a García Monge quienes en sus novelas, primeras de la literatura costarricense, muestran ese antagonismo entre el campo y la ciudad. El campo es "el espacio idílico de la paz en que el patriarcalismo triunfa" en cambio la ciudad es “donde se escenifica la etapa final del proceso de degradación de los valores del mundo patriarcal” (Amoretti: 1995, 68).

${ }^{6}$ Gallardo, Isabel y Picado, Olga (1984). Análisis del discurso crítico costumbrista (Aportes para una historia del pensamiento literario en Costa Rica).Tesis. San José: Universidad de Costa Rica.

${ }^{7}$ Lo que en teoría literaria se llama Locus amoenus: "la traducción literal de locus amoenus sería "lugar ameno o bonito". Pero... podemos entender mejor acudiendo a la definición de Ángel González, que explicaba el tópico de 'locus amoenus' como un "lugar propicio para el amor", para el disfrute, para el gozo (Ortiz, 2010: s.n.p).

${ }^{8}$ Aunque, según Cros (1986a: 69) y Amoretti (1992), se debería hablar de sociocrítica y no de la sociocrítica.
} 
mueve en un contexto cultural específico, escribe basado en una infinidad de textos o enunciados que han sido pronunciados desde generaciones anteriores en ese mismo contexto.

Ante lo cual, María Amoretti dice:

Por eso se dice que el escritor o el poeta no escoge sus palabras en el diccionario, sino en el contexto de lo vivido, en donde han surgido y llegado a su adultez impregnadas ya de cierta valoración" (Amoretti: 1995: 23).

Cros, en sus conferencias sobre sociocrítica, cita a Julia Kristeva quien sostiene que "un texto siempre está escrito con arreglo a otro texto; aquel está reconstruyendo a este y el texto nuevo redistribuye los elementos anteriores" (Cros, 1986b: 78).

En el caso de tomar la música como texto, Gerardo Meza (1997) indica que, como práctica social, la música es un texto que reproduce y reelabora otros textos de la cultura general, sincrónica y diacrónicamente. A eso agrega:

... y no solo como estructura puramente formal, lo podríamos considerar como una producción dinámica y transformativa que distribuye y retoca, que reproduce textos y no una simple reproducción de "sentimientos" sonoros o gráficos, y que además no entra en el juego de lo falso y verdadero. (Meza, 1997: s.n.p.)

De acuerdo con lo anterior, la intertextualidad en la música se presenta al retomar las formas tradicionales de composición con su armonía, sus giros melódicos, ritmos característicos y estructuras y reproducirlas o transformarlas. Las canciones estudiadas fueron compuestas siguiendo el "Paradigma de la música tonal" (Carmona, 2006:
100), sin pretensiones de innovar o transformar pero, lo más importante, sí tratando de seguir o representar el texto poético. Ahí, según Meza, estaríamos pensando la música como un texto inserto en una ideología, como un fenómeno translingüístico que reduce y transforma textos de otros lenguajes con los que dialoga.

Para el análisis de la música propiamente, se utilizan las herramientas de la musicología expuestas por el Dr. Dieter Lehnhoff. El objeto de estudio de la musicología son las obras musicales y su ubicación en un contexto, trata de su descripción y reflexiona sobre ellas. (Lehnhoff, 2005); de ahí que en esta investigación se han tomado de la musicología sistemática las herramientas que permitan la descripción de los aspectos formales de las obras que integran el corpus. De cada una se han analizado los aspectos rítmicos, armónicos y de forma para buscar la relación intertextual entre texto y música.

Se presentarán los análisis según la temática, en primer lugar, las canciones infantiles de las que se tomaron El lecherillo y Somos marineros ${ }^{9}$. Luego, de las canciones dedicadas a la madre, Santa y bella. En tercer lugar, de las canciones dedicadas a la patria o a lugares específicos: En Puntarenas, Golfito y ¡Oh Costa Rica!. Por último, de las que evocan el locus amoenus: Casita en que nací y Caña dulce. Esta última se ha tomado en cuenta debido a su importante presencia en el ambiente cultural y educativo del país. En el anexo de este artículo se encuentran las partituras de las canciones estudiadas tomadas del disco Cantos de poetas (Carmona, 2016), ahí se podrán ver los nombres de los compositores y poetas y los textos completos.

\footnotetext{
${ }^{9}$ De todas estas canciones existe la partitura original del compositor con su melodía y acompañamiento excepto de Somos marineros. El acompañamiento de esta melodía lo escribió la M. M. Katia Guevara Rojas especialmente para este proyecto.
} 


\section{El lecherillo}

Es, claramente, una canción infantil que apareció ya desde la primera edición de Lo que se canta en Costa Rica (Zúniga, 1933b: 20). El ritmo de la música calza perfectamente con la letra y cada estrofa tiene su música diferente con un ritmo distinto para ayudar a diferenciar la temática de la letra.

La canción tiene forma A-B-C-A y está en re mayor. Entre A y B, incluye un silbido imitando el llamado de un lechero cuando llega a dejar la leche. La sección A utiliza, casi todo el tiempo, la síncopa de semicorchea-corchea-semicorchea. En $\mathrm{B}$ usa un ritmo de negra con dos corcheas y, en C, la característica es el uso del tresillo que alterna con grupos de dos corcheas. Finalmente, retoma el tema A con la última estrofa de la canción. Está muy bien utilizado cada ritmo de la música para seguir el ritmo del texto.

En general, la realización del acompañamiento está bien logrado, desde el punto de vista pianístico. El bajo, sobre todo en la sección B, es muy dinámico y tiene algunas progresiones armónicas y cromatismos interesantes.

\section{Somos marineros}

Es una canción infantil muy alegre en la que los personajes juegan a ser marinos que exaltan felices la vida en su barco y en el mar. En toda la canción, letra y música van de la mano y el ritmo de marcha refuerza el sentido de juego. Tiene dos secciones, en la primera (A) describe quiénes están narrando: felices marineros que van a la mar muy orgullosos de su barco. La música está en re mayor e inicia con una secuencia ascendente. La figura dominante es la corchea con puntillo y semicorchea (saltillo). En la segunda frase, llega al punto más agudo cuando dice que "vivimos felices". Termina esta sección con una repetición de la primera frase variada haciendo vivas a su barco.

En la segunda sección, la música modula a sol mayor y la figura dominante es la negra. En ella llama a la marcha para ir a bogar pues, dice, "ya nuestras vidas han de ser del mar".

\section{Santa y bella}

Es, quizá, la canción más popular del repertorio ramonense. Se puede observar en ella una gran relación entre el significado del texto y la música. Por ejemplo: en el inicio, cuando el narrador describe: "tiene los cabellos blancos, muy arrugada la frente..." la música es tranquila y un poco grave. En el momento en que dice: "pero es la más bella de todas las mujeres", la música se eleva al registro más agudo de la canción.

En la segunda sección, cuando el narrador dice la palabra "Madre" lo hace con notas largas en el momento de la modulación a sol mayor. Aquí la música tiene ritmo de bolero y es más brillante, le da un énfasis especial a la palabra "madre", que es central en la canción.

\section{En Puntarenas}

Esta canción se publicó desde la primera edición de Lo que se canta en Costa Rica (Zúñiga, 1933b: 81). Incluso, ya había sido editada en las colecciones de partituras de canciones publicadas en 1933 por José Daniel Zúñiga. (Zúñiga, 1993a: s.n.p.)

Desde el punto de vista rítmico, la música calza con la letra. Aunque es notorio que no fueron pensadas para ser una unidad. Tanto es así, que la primera estrofa del poema se repite con melodías diferentes. La música combina varios géneros: es una habanera que cambia varias veces de ritmo durante la pieza. Gracias a estos cambios de velocidad y en el figureado rítmico, la canción presenta una gran variedad.

Resultan interesantes esos cambios de tempo que se dan para ambientar mejor cada estrofa del poema. Inicia con una introducción con tempo Allegretto en la que incluye la indicación: "Imitando a la marimba tica". En la sección A, con la indicación Menos, las imágenes que evoca el poema hablan de un ambiente marino con las olas y la espuma del mar que en la playa "vibrando queda como heliotropo que se desmaya". Imagen muy sensual que evoca una mujer que se rinde cansada en la playa después del éxtasis. Esta imagen es reforzada por la sensualidad del ritmo de habanera y los giros melódicos ondulantes. 
En la sección B, Movido a tempo, el carácter de la música cambia al cambiar la temática del poema. Son los versos en que habla de un marinero que "fuma cachimba". En esta sección modula a la relativa menor y las figuras rítmicas dominantes cambian a tresillos. Viene luego una transición instrumental modulatoria de cuatro compases con tempo Un poco movido. Inicia en la dominante para llegar a la paralela mayor de la tonalidad en que venía.

La sección C, Moderato dolce, vuelve al ritmo de habanera para reforzar la imagen de la morena "de ojos quemantes y curvaturas hechas pecado" de la que habla el poema. En esta sección, el discurso musical es interrumpido por algunos calderones que ayudan a reforzar palabras importantes. Por ejemplo, justo antes de la palabra pecado, hay un calderón sobre el silencio de semicorchea anterior. Algo similar hace cuando dice que los marineros siguen a la morena "para el... (pausa) mercado". Por último, en la sección D indica Movido. El ritmo es derivado de la sección B. Musicalmente, es la sección más dramática. Termina con un dal segno al fine (tema C) para finalizar en la relativa mayor.

\section{Golfito}

Tiene forma A-B. En la primera sección, la primera estrofa de la canción habla de "gigantes frondas" que vigilan a los hombres en su trabajo. En ese punto, la música utiliza una melodía ondulante con intervalos amplios como representando las altas montañas y los espesos bosques. En la segunda frase inicia con una melodía descendente. Los intervalos son pequeños, casi como jugando, posiblemente porque describe cómo el sol desciende de las montañas "con la gracia de un rapaz". En toda esta sección, al igual que la letra, la música es tranquila, con un ritmo de barcarola.
Para las últimas dos estrofas, sección B, continúa en la misma tonalidad pero cambia el ritmo radicalmente al de habanera y es a dos voces. La música es más movida porque la letra habla del movimiento de los botes y los barcos y del trabajo de los hombres empleados de la compañía bananera.

\section{¡Oh Costa Rica!}

Este himno apareció en la primera edición de Lo que se canta en Costa Rica. Fue uno de los himnos patrióticos más cantados por muchas las generaciones de escolares y colegiales. En la actualidad, se ha dejado de cantar y los jóvenes universitarios ya no lo conocen.

Es una marcha en $6 / 8$ que está en sol mayor y con forma A-B-A-C-A-B. Su intertexto más evidente es el Himno Nacional ya que, en la introducción y en los compases 90 y 91, hace citas directas de la música de este. La letra y la música es muy probable que fueran escritas en momentos diferentes, ya que existe otra marcha con esta misma letra con música de Víctor Manuel Sanabria León (Sanabria, 1927: manuscrito). Sin embargo, la música contribuye notablemente a exaltar el texto poético.

Luego de la introducción, comienza la sección A con una melodía que hace una secuencia rítmica con giros melódicos ascendentes. En la segunda frase realiza una interesante modulación a si menor y es el piano el que retoma la tonalidad original para modular a la paralela menor y conducirnos a la sección $B$. En esta sección el texto habla de que en la patria guardamos un pasado lleno de gloria y amor, y ella es como una madre llena de honor ${ }^{10}$. Aquí, el intertexto es el pasodoble. Los giros melódicos evocan la música española posiblemente rememorando el pasado y sus glorias y porque España es la "madre patria". Además, llama a Costa Rica "madre virtuosa llena de honor" cumpliendo lo que Amoretti indica acerca de la visión fisiocrática de la patria ${ }^{11}$. En la tercera parte, vuelve la música

\footnotetext{
${ }^{10}$ Existe una incongruencia entre las ediciones de esta canción ya que algunas utilizan la palabra honor y otras amor. Se ha utilizado la palabra honor pues es así como aparece en el libro Lo que se canta en Costa Rica (Zúñiga, 1981: 122)

${ }^{11}$ Amoretti llama "concepción fisiocrática" de patria a "una apología a la fecundidad de la tierra, ella es madre generosa que todo lo da sin reclamar nada. Bajo su protección el hombre tiene asegurada la satisfacción de sus elementales necesidades y siendo todos hijos de ella, son todos también entre sí hermanos" (Amoretti, 1995: 37-38).
} 
marcial de A para finalizar con un giro melódico conclusivo. La cuarta parte $(\mathrm{C})$ está en do mayor y la melodía se hace más tranquila con notas largas. En ella se describe la bandera y el significado de sus colores. En el momento en que el himno dice que ella es la que cuida nuestra ventura y es el escudo que resguarda nuestra paz, la música va creciendo no solo en volumen sino, también, en intensidad. Es el punto culmen de la pieza. Para reforzar su identificación con la patria, en el momento que está diciendo la palabra escudo, con notas largas en la melodía, en la mano izquierda hace cita directa de los tresillos del bajo del Himno Nacional.

\section{Casita en que nací}

La canción tiene ritmo de pasillo pero, de manera diferente al pasillo tradicional que -generalmente- inicia con una anacrusa de cinco notas, en esta canción la ancrusa es solo de una nota. Su forma es $\mathrm{A}-\mathrm{A}^{1}-\mathrm{B}-\mathrm{A}^{1}$ con una estructura tradicional de 16 compases por sección y la sección $\mathrm{B}$ está en la relativa mayor. Utiliza la armonía funcional y es destacable la escritura del acompañamiento del piano pues muestra una manera original de escribir el ritmo de pasillo que, generalmente, es difícil para el piano.

Según Carlomagno Chacón Araya, nieto de Carlomagno Araya, la poesía no fue escrita como canción ya que no está como tal en el catálogo de la obra de Araya (Chacón, 2015: comunicación vía correo electrónico). Esta canción no estaba incluida en la primera edición de Lo que se canta en Costa Rica. Existe una estrecha relación entre el sentido de la letra y los giros melódicos, lo cual es notorio, especialmente, en la última estrofa cuando dice "cantar mis madrigales más sentidos", ahí la música ayuda a enfatizar el verbo cantar. Al final del verso, la melodía termina con una melodía descendente.

Al inicio de la canción, cuando el narrador dice "casita mía" la música asciende y hay una pausa luego para repetir la palabra "casita" en la parte más aguda de la frase musical. En la sección $\mathrm{A}^{1}$, a partir de "cantan los yigüirros en tu alero" la música va ascendiendo en cada semifrase para enfatizar "casita singular que tanto quiero" y finaliza la sección con una melodía descendente al decir "qué cambiada que estás y qué distinta”.

En $B$, además de la tonalidad, cambia un poco el ritmo cuando el narrador le dice a la casa "fíjate bien en mí ¿no me conoces?” Termina la canción con una reexposición de $\mathrm{A}^{1}$ con una pequeña variación para finalizar.

\section{Caña dulce}

Es una de las canciones emblemáticas del repertorio costarricense, pues ha sido arreglada para innumerables conjuntos musicales y ha sido grabada en muchísimas versiones. Además, se ha enseñado en las instituciones educativas por muchas generaciones. Según Norma Lorena Portuguez Zúñiga, nieta del compositor José Daniel Zúñiga, José Joaquín Salas Pérez, autor de la letra de muchas de las canciones de Lo que se canta en Costa Rica, le solicitó a Zúñiga que le pusiera música a su poesía (Portuguez, 2016: contacto personal). Aunque la letra se dio primero, el compositor captó el mensaje del poema y logró que la música le diera realce.

La canción está en re menor y tiene forma A-B-C da capo ${ }^{12}$. En la sección A, donde el narrador habla (en primera persona) de su proyecto en el que tendrá sus cultivos, su mujer y será feliz, la melodía tiene dos partes, la primera con pequeños giros ascendentes y la segunda con intervalos más amplios. Cada vez que inicia la melodía, va conduciendo al escucha hacia el clímax de la frase en la segunda parte. En esa segunda frase, las tres veces que se canta, habla de la suerte, de la felicidad y que ya no tendrá más preocupaciones. Es decir, la música resalta el mensaje positivo en las notas más agudas de la sección.

La sección B es un interludio instrumental con ritmo de bolero en el que la música modula a la paralela mayor. Cuando el narrador habla de los resultados que espera de su trabajo y de un futuro promisorio, en la sección C, siempre en re mayor, los

\footnotetext{
${ }^{12} \mathrm{Da}$ capo (D. C.) signo que indica que la música se debe repetir total o parcialmente.
} 
giros melódicos presentan intervalos más amplios. También, la melodía llega a sus puntos más agudos $\mathrm{y}$ tiene ritmo un poco mecido como evocando el baile de los enamorados.

\section{Discursos en las canciones}

Carvajal (2013: 158), dice que "los discursos fungen como instrumentos mediáticos que refuerzan determinadas ideologías". Según Cros, el autor, en su formación social, adquiere una serie de discursos "a través de la formación discursiva, la cual no es más que la concretización de la formación ideológica, que es el producto de la formación social" (Cros, 1986b: 78). Tal práctica es la interdiscursividad, de la que Mijail Bajtín explica que, en todo enunciado, "podemos descubrir una serie de discursos ajenos, semiocultos e implícitos y con diferentes grados de otredad ${ }^{13}$ ".

Jorge Ramírez lo resume así: "Una lectura interdiscursiva, entonces, tendría como finalidad identificar las huellas discursivas de una formación ideológica y los contornos de la formación social correspondiente" (Ramírez, 2000: 147). De esta manera, si el analista puede definir el interdiscurso presente en la obra analizada, podrá "leer" en el texto, las condiciones socioculturales, sociopolíticas y socioeconómicas del autor. Este último aspecto es básico en el presente trabajo de investigación ya que, como se verá, el componente socioeconómico está presente en la mayoría de los textos propuestos en el corpus y es lo que se analiza a continuación.

Existen una serie de valores implícitos en estas canciones. Son los mismos que se pueden encontrar en la literatura de principios del siglo XX, y que son derivados, en gran medida, de la visión de mundo que muestra el Himno Nacional y que, como se dijo anteriormente, ha marcado la literatura y la educación costarricenses desde su creación. María Amoretti corrobora lo anterior cuando asegura que "el efecto de sencillez que genera el himno, un inigualable compendio ideológico, invade el sentido auténtico de la vida y para ser natural, también auténtica, la literatura debe reflejarse en espejo frente a ese valor" (Amoretti, 1995: 70).

Uno de los discursos más importantes, es el de la relación madre-patria. En ¡Oh Costa Rica! se hace un homenaje a la patria y se ensalzan todas sus virtudes. En la sección $\mathrm{B}$ de este himno dice directamente: "en ti ciframos toda esperanza madre $^{14}$ virtuosa llena de amor". Por su parte, en la última estrofa de Santa y bella dice: "Madre yo te ofrendo mi vida, madre yo que te entrego mi amor oye mi canción más sentida que feliz este día te da mi corazón". Si tomamos el concepto fisiocrático de "patria-madre" de esta segunda canción como equivalente a patria, esa "canción más sentida”, perfectamente, podría ser ¡Oh Costa Rica! en cualquier celebración patriótica. Además, es oportuno recordar lo que dice Amoretti en el caso de la utilización cristiana del verbo dar (ofrendar o entregar, en este caso): quien da, recibirá; quien ha recibido, deberá pagar dando ${ }^{15}$ (Amoretti, 1995: 50).

Otro de los discursos ocultos que se pueden encontrar a través de las canciones es el tema de la dicotomía campo-ciudad, muy utilizado en la literatura de inicios de siglo XX. En ninguna de las canciones se menciona la ciudad. La mayoría, más bien, hace alusión a la vida en el campo, temática recurrente seguramente porque, a inicios de siglo y luego de fuertes discusiones en el medio cultural costarricense, se impuso el discurso nacionalistacostumbrista en la literatura nacional. Parte fundamental de ese discurso es la recreación de escenas de la vida típica del costarricense de campo.

\footnotetext{
${ }^{13}$ M. Bajtín Estética de la creación verbal (traducción de Tatiana Bujnova) segunda edición, México Siglo XXI, 1985) p. 283 citado por Quesada 1994.

${ }^{14}$ Resaltado nuestro.

${ }^{15}$ Según la M. L. María del Carmen Mauro, existen muchos semas religiosos que conforman una parte muy importante de la ideología liberal y de su forma de dominio. (Mauro, 2016: contacto personal).
} 
En palabras de Margarita Rojas:

En esa imagen nacional el espacio es cerrado, conocido, pequeño y acogedor; generalmente, el tiempo es el momento idealizado de la infancia pero siempre un pasado, superior al presente, y el sujeto nacional es parte de una familia rural, sin conflictos internos y organizada según una jerarquía patriarcal (Rojas, 1998: 35).

El panorama así expresado conduce al discurso de que "es en la ciudad en donde se escenifica la etapa final del proceso de degradación de los valores del mundo patriarcal" (Amoretti, 1995: 68 ) en contraposición de la vida humilde, sencilla y virtuosa del campo. En varias de las canciones es posible detectar el discurso del locus amoenus. El campo es idealizado como un lugar en el que se cumplen nuestros sueños y podemos ser felices. Ese discurso está presente en Caña dulce, Casita en que nací, El lecherillo, En Puntarenas, Golfito y Somos marineros.

Para ejemplificar atiéndase la temática de Caña dulce, Somos marineros, El lecherillo y Golfito. En ellas se hace mención de la naturaleza, del trabajo en el campo, del trabajo de la tierra y todos los beneficios y toda la felicidad que nos pueden brindar, aunque tales trabajos no generen remuneración alguna ni creen acceso a bienes materiales. Otro ejemplo es la Casita mía, que representa a la casa pero, también, podría representar la campiña, el pueblo, el valle, el país... En palabras de Mauro (2016) es el "útero afincado en la "madre tierra".

El diminutivo "casita" tiene una importancia especial pues refuerza la imagen de casa humilde y querida. Es el mismo discurso del Himno Nacional que representa la pequeña aldea pobre que era Costa Rica a finales del siglo XIX y principios del XX.

A partir de este punto, es necesario hacer una mención aparte de la canción Golfito. En ella, además de exponer la belleza natural en torno al pueblo de Golfito, es posible encontrar otro discurso singular que se puede apreciar observando los verbos que utiliza en el texto: "vigilan", "batallar", "arrancan", "corren" y "cargar". Golfito fue parte importante del enclave de la Standard Fruit Company en el Pacífico Sur con todos los problemas de índole laboral que provocó esa compañía en Centroamérica (Abarca, 2013: s.n.p.). Si se observa con cuidado el tipo de verbos utilizados en la canción, podría interpretarse que hablan de que el arduo trabajo que realizaban los trabajadores, empleados bananeros corriendo y batallando contra el clima y la insalubridad para arrancar a la tierra sus productos y cargarlos a los trenes y barcos de la Compañía, era vigilado por las "gigantes frondas" que aquí podrían representar, precisamente, a la compañía bananera.

Finalmente, hay un discurso socio-económico que atraviesa las canciones como un eje transversal. De todas, excepto de Santa y bella y ;Oh Costa Rica!, es posible inferir el discurso del "labriego sencillo", imagen creada en el Himno Nacional: el de las clases bajas, pobres y humildes. Se refuerza el concepto de que la pobreza, la humildad y la sencillez son valores cristianos de los que hay que estar orgulloso. Por ejemplo: los personajes como el lecherillo, los marineros, los trabajadores de Golfito y todos los mencionados en En Puntarenas, siempre son humildes y pobres. Además, en ninguna de las canciones se hace alusión a personajes o situaciones de las clases altas como posesiones, palacios, etc. Incluso, la Casita en que nací muestra un serio deterioro producido por la falta de un mantenimiento adecuado y en Caña dulce, explícitamente, dice que teniendo unas pocas cosas materiales y a su mujer, el narrador será tan feliz "como esos reyes que no envidian ya nadita".

Este discurso socioeconómico remite constantemente a un hogar pobre en el que, a pesar de la escasez de recursos económicos, había belleza y seguridad. Esa imagen de que el pueblo costarricense siempre fue pobre y ese mandato de la tradición cristiana que de los pobres será el Reino de los cielos (Mt. 5:1-5 ${ }^{16}$ y, que los ricos son

\footnotetext{
16 "Dichosos los pobres en espíritu, porque el reino de los cielos les pertenece. Dichosos los que lloran, porque serán consolados. Dichosos los humildes, porque recibirán la tierra como herencia." (MT. 5: 1-5)
} 
malos (Lc. 18-25; Prov. 11:28; Mt. 19:14 ${ }^{17}$ ) todo eso, aunado a la conciencia que habían adquirido los gobernantes del país sobre el poder de la educación y la música en el "adoctrinamiento" del pueblo, es muy probable que haya sido aprovechado por los liberales en el poder, para instaurar un sistema educativo con ese fin.

Por otra parte, es notoria la ausencia de una visión de mundo femenina debido a la falta de escritoras en todo el corpus analizado. En la mayoría de las canciones incluidas en los libros estudiados, la letra y la música fue escrita por hombres. Hay muy pocas canciones escritas por mujeres. Por eso mismo, la visión de mundo que se establece con ellas y su modelo ideológico es androcéntrico, propio de una sociedad patriarcal.

Se requiere tomar en cuenta que las canciones infantiles preparan a los niños y a los jóvenes para la vida cotidiana. Transmiten valores y refuerzan identidades. Pero, sobre todo, imprimen una visión de mundo que trascenderá al resto de su vida. Sobre todo, como dice Carvajal, porque son cantadas repetidas veces en conjunto con sus congéneres y profesores. Del corpus escogido El lecherillo y Somos marineros son, directamente, canciones infantiles con las que es posible diseñar rondas, juegos de manos y demás recursos didácticos que acompañan la educación musical. Pero todas las canciones son de lo que se canta en Costa Rica en escuelas y colegios.

Por otro lado, esa identidad tan costarricense también es posible transmitirla al mundo mediante las canciones artísticas, como las llama Matarrita. Al ser un repertorio que se puede cantar en cualquier sala de conciertos por cantantes líricos, es posible dar a conocer nuestra cultura, no solo musical, sino en general. En esta categoría de canción artística o de repertorio universal, por su elevado nivel musical y por la profundidad de su poesía, podemos ubicar Casita en que nací, En Puntarenas, Caña dulce, Golfito y Santa y bella.
En opinión de quien escribe, cualquier público podrá apreciar la calidad de esta música. Pero son todas las canciones estudiadas y las incluidas en estos libros, las que deberían ser conocidas y apreciadas, en primer lugar, por todo el público costarricense debido a su valor musical y su belleza estética con el fin, especialmente, de reforzar la identidad musical costarricense. Para ello, será necesaria su presencia en el sistema educativo nacional con la consciencia, eso sí, de que se trata de una visión ideológicamente androcéntrica que debe ser tratada como corresponde. Con ello, los compositores del futuro, que son niños en este momento o no han nacido, crearán música con tales discursos en su subconsciente y tendrá una identidad y una visión de mundo muy costarricense.

\section{Visión de mundo}

Cros, al citar a Lucien Goldmann, dice que la visión de mundo "es el conjunto de aspiraciones, frustraciones, de los sentimientos y de las ideas que reúnen a los miembros de un grupo determinado y los distingue a los demás." (Cros: 1986a: 72) En el caso de las canciones analizadas, como se ha observado anteriormente, su referente ideológico y el discurso dominante es la letra del Himno Nacional y el paradigma creado alrededor de la figura del "labriego sencillo" según lo ha expuesto María Amoretti (1995).

Cuando se analiza cualquier texto, es posible encontrar que existe presencia de diferentes discursos sociales, culturales y económicos. De esta manera, cuando nos enfrentamos al corpus escogido, encontramos los discursos que nos sitúan en el cronotopo de la Costa Rica de la primera mitad del siglo XX: una Costa Rica que se caracterizaba por un bajo desarrollo económico, por falta de vías de acceso que facilitaran a los campesinos sacar sus productos a la venta, por una economía fundamentada en un monocultivo... por todo lo anterior, la familia costarricense de la época era

18 "Porque es más fácil que un camello pase por el ojo de una aguja, que el que un rico entre en el reino de Dios." (Lc. 18-25; Mt. 19:14) "El que confía en sus riquezas, caerá, pero los justos prosperarán como la hoja verde” (Prov. 11:28) 
una familia pobre y vivía en "casitas" humildes y aisladas del resto de la sociedad. Precisamente, como imaginamos al San Ramón de la primera mitad del siglo XX.

El siglo XX en Costa Rica arranca con una fundamentación ideológica que parte del estilo costumbrista, en la literatura, y la letra del Himno Nacional, la cual, según Amoretti (1995: 32), fue escrita por José María (Billo) Zeledón basado en la Primera Proclama del presidente Juan Rafael Mora, previa a la guerra de 1856 . En estos textos se manifiestan las bases del discurso socioideológico del ser costarricense cuales son: el campesino como base de nuestra sociedad, la patria como la madre que a la vez está valorada como tierra (patriamadre-tierra ${ }^{18}$ ); cuyo hijo, el labriego sencillo, está dispuesto a defenderla en cualquier momento. La visión de mundo resultante es: vivir en esta madrepatria, pobre, aislado en el campo, cultivando la tierra, sin apego a los bienes materiales (los cuales, prácticamente, hay que rechazar), pero feliz y agradecido por la libertad. En el mismo sentido, acerca del humor del campesino costarricense, expuso Emilia Prieto:

En cuanto a la humildad y sencillez, la ausencia absoluta de presunción y arrogancia que hay en nuestros campesinos y la manifiesta aversión que le profesan a quienes de tales vicios adolecen, todo, revela una clara y ágil inteligencia que viene a combinarse con la hilaridad en una manera muy propia, franca y graciosa que tienen hasta para reírse de sí mismos. (Prieto, 1978: 161)

Así, el campesino costarricense ha sido objeto de múltiples creaciones culturales: cuentos, novelas, "concherías", leyendas, canciones, himnos, esculturas, pinturas, etc. De manera que estas prácticas discursivas remiten a su modus vivendi y al modelo ideológico que resalta su valor, su dignidad, en la construcción de la sociedad costarricense. Los textos musicales abordados en esta investigación, siguen esta línea ideológica y muestran los diferentes interdiscursos que remiten al modo de ser del costarricense, según lo que establece el Himno Nacional y los subsiguientes textos que surgen de la propuesta inicial en los albores del siglo XX, marcados, además, por ser todos autores del mismo origen.

Se registra una tendencia a idealizar esa Costa Rica en general y a San Ramón en especial, como un locus amoenus, un paraíso terrenal idílico que en un tiempo pasado fue bello y tranquilo. De ahí la evocación romántica de la casa familiar, del puerto de Puntarenas y de las actividades que se podía realizar en ellos.

Critica María Isabel Carvajal en su libro sobre el Himno Patriótico al 15 de setiembre (2013: 157) que esa imagen de país es una "idealización nostálgica de una Costa Rica que ni existió ni existe como tal". Creemos que sí, que es una imagen creada por el sistema liberal imperante en la época para imponer sus fundamentos ideológicos, pero logró marcar, en gran medida, la producción literaria, educativa e, incluso, la musical. Agrega Carvajal, "el costarricense presente en el discurso de este himno es (únicamente) el del Valle Central, ya que eran "labriegos sencillos. Los pescadores, las poblaciones negra e indígena, las mujeres y los trabajadores de otra índole no forman parte de él". Sin embargo, en las canciones analizadas sí están presentes otros pobladores diferentes a los del Valle Central. En ellas se menciona a Puntarenas y Golfito y a sus pobladores. A esas dos canciones se les suma Somos marineros exaltando la vida en el mar. Seguramente, porque San Ramón, a pesar de estar en el Valle Central, vivió aislado del resto del país por falta de buenas vías de acceso y más cercano al mar.

Es una tarea difícil encontrar factores en común en canciones con temáticas y músicas tan variadas y diferentes; sin embargo, luego de

\footnotetext{
${ }^{18}$ La M. L. Carmen Mauro ha aportado el concepto de "matria” abstrayendo en uno solo, estos otros tres conceptos
} (Mauro, 2016: contacto personal) 
analizarlas, es posible encontrar que las relaciones interdiscursivas y la visión de mundo, coinciden en muchas de ellas. En especial, por tratarse de autores que nacieron y crecieron en esa "minúscula ciudad letrada” como la llama Francisco Rodríguez (2014), que es San Ramón.

Hay un diálogo permanente entre los intertextos y los interdiscursos y es posible considerar la fuerte influencia que el modelo propuesto por los grupos de poder ha tenido siempre sobre el inconsciente colectivo de los costarricenses. Por ello, resulta importante seguir revisando todos los objetos culturales propios de esa dinámica ideológica, entre ellos, la música.

Esta es solo una pequeña muestra del amplio panorama de la canción costarricense y no quiere decir que en todas las canciones de Lo que se canta en Costa Rica están incluidos tales discursos, aunque es muy probable que sí. Queda el tema abierto para ser ampliado en nuevas investigaciones para que conozcamos, cada vez más, nuestro país y nuestra cultura nacional. Con ello cumpliremos con Emilia Prieto quien afirmó:

Conocerse a sí mismo es lema aplicable a pueblos. Es derrotero que conduce a la autonomía, al crecimiento, al desarrollo sin "sub", a la afirmación de la nacionalidad y la cultura. (Prieto, 1978: 131) 


\section{Bibliografía}

Abarca Vásquez, Carlos (2013). “Costa Rica. El sindicalismo bananero del Pacífico Sur en la década del 60". http://www.monografias.com/ trabajos95/costa-rica-sindicalismo-bananerodel-pacifico-sur-decada-del-60/costa-ricasindicalismo-bananero-del-pacifico-surdecada-del-60.shtml\#ixzz31Vqm68mk

Alpízar Rojas, Marco Tulio (2015). Los maestros de música en San Ramón, su legado y aporte a la educación musical y a la música del cantón de 1900 a 1960. Propuesta de aprovechamiento didáctico. Tesis para optar al título de licenciado en música con énfasis en educación musical. Heredia: Universidad Nacional.

Amoretti, María (1995). Debajo del canto. Un análisis del Himno Nacional de Costa Rica. San José: Editorial de la Universidad de Costa Rica. Primera reimpresión.

Carmona Ruiz, Jorge Eduardo (2001). Música costarricense para piano a cuatro manos. San José: Editorial de la Universidad de Costa Rica.

Carmona Ruiz, Jorge Eduardo (2006). "Nuevos signos para sonidos viejos. La utilización de nuevas gracías en dos sonatas para piano centroamericanas". En: Revista Pensamiento actual. Volúmen 6, N. ${ }^{\circ}$ 7. Páginas 97 - 113.

Carmona, Jorge (2016). Cantos de poetas. Veinticinco poesías musicalizadas de autores ramonenses. San Ramòn: disco coproducido por el CIDICER de la Universidad de Costa Rica y el ICAT de la Universidad Nacional.

Carvajal, María Isabel (2011). “Construcción imaginaria de Costa Rica en textos históricos e himnos". En: Revista Herencia. Vol. 24 (1 y 2). San José, Programa de Rescate y Revitalización del Patrimonio Cultural.
Carvajal, María Isabel (2013). El Himno Patriótico al 15 de Setiembre en el imaginario costarricense. San José: Editorial de la Universidad de Costa Rica.

Chavarría, Lisímaco (2013). Obras completas. Edición de Francisco Rodríguez. San José: Editorial de la Universidad de Costa Rica.

Cros, Edmond (1986a). "Introducción a la Sociocrítica” (Conferencia No. 1). En: Revista Káñina, Rev. Artes y Letras, Univ. Costa Rica. Vol. X (1) (Pág. 69-76).

Cros, Edmond (1986b). "Introducción a la sociocrítica”. (Conferencia No. 2). En: Revista Kánina, Rev. Artes y Letras, Univ. Costa Rica. Vol. X (1). San José: Editorial de la Universidad de Costa Rica (Pág. 77-84).

Lehnhoff, Dieter (2005). Exposición de cátedra, apuntes inéditos del curso "Música del siglo XX en Centroamérica del Doctorado Interdisciplinario en Letras y Artes en América Central.

Matarrita Venegas, Manuel (2009). Canciones populares costarricenses. San José: Editorial de la Universidad de Costa Rica.

Mauro Valdeperas, María del Carmen (2016). Contacto personal.

Meza, Gerardo (1997). Lectura para una Lectura del Texto Musical. Música y relaciones intertextuales. Inédito.

Ortiz, Miguel (2010). “Diccionario Literario: Locus amoenus". http://www.papelenblanco.com/ diccionario-literario/diccionario-literariolocus-amoenus

Pineda González, Miriam (2016). Entrevista telefónica.

Portuguez Zúñiga, Norma Lorena (2016). Contacto personal. San José, Universidad de Costa Rica. 
Prieto, Emilia (1978). Romanzas ticomeseteñas. San José: Imprenta Nacional.

Quesada López, Juan Ernesto y Juan Rafael Camacho Vargas (2004). Época de oro de la música escolar costarricense. San José: Editorial de la Universidad Estatal a Distancia.

Quesada, Sonia (1994). Viaje al reino de los deseos intertextualidad y era cibernética. Tesis para optar al grado de Magíster literarum. San Pedro: Universidad de Costa Rica.

Ramírez Caro, Jorge (2000). Lecturas intertextual e interdiscursiva en sociocrítica. http://www. revistas.una.ac.cr/index.php/letras/article/ view/3687

Ríos González, Gabriela (2013). “Cuando apunte el verolís. ¿El qué?. En: Káñina, Revista Artes y Letras, Universidad de Costa Rica. P. 101-144. http://revistas.ucr.ac.cr/index.php/kanina/ article/view/10574/9966

Rodríguez, Francisco (2014). “San Ramón, tierra de poetas". Ensayo introductorio para la Historia de la literatura ramonense. Inédito.

Rojas, Margarita (1998). "Entre la aldea y el mundo". En: Re-visión de un siglo 1897-1997. San José: Museo de Arte Costarricense.

Rojas, Margarita y Flora Ovares (1995). 100 años de literatura costarricense. San José: Ediciones Farben-Grupo Editorial Norma.

Sanabria, Víctor (1927). ¡Oh, Costa Rica!. Manuscrito.

Trottier, Danielle (1994). Juego textual y profanación. San José: Editorial de la Universidad de Costa Rica.

Vargas Cullell, María Clara (2004). De las fanfarrias a las salas de concierto. Música en Costa Rica (1840-1940). San José: Editorial de la Universidad de Costa rica
Zúñiga, José Daniel (1933a). Canciones escolares. San José: Imprenta nacional.

Zúñiga, José Daniel (1933b). Lo que se canta en Costa Rica. Primera edición. San José, Imprenta Lil, S. A.

Zúñiga, José Daniel (1976). Álbum de la patria. Segunda edición, aumenada y actualizada. San José: Departamento de publicaciones del Ministerio de Educación Pública.

Zúñiga, José Daniel (1980). Lo que se canta en Costa Rica. Décimosegunda edición. San José: Imprenta Lil, S. A. 


\section{Anexo}

El lecherillo
Música: Tertuliano Mora Pacheco.

Letra: Marco Tulio Castro.

Edición: Jorge Eduardo Carmona Ruiz 2015.
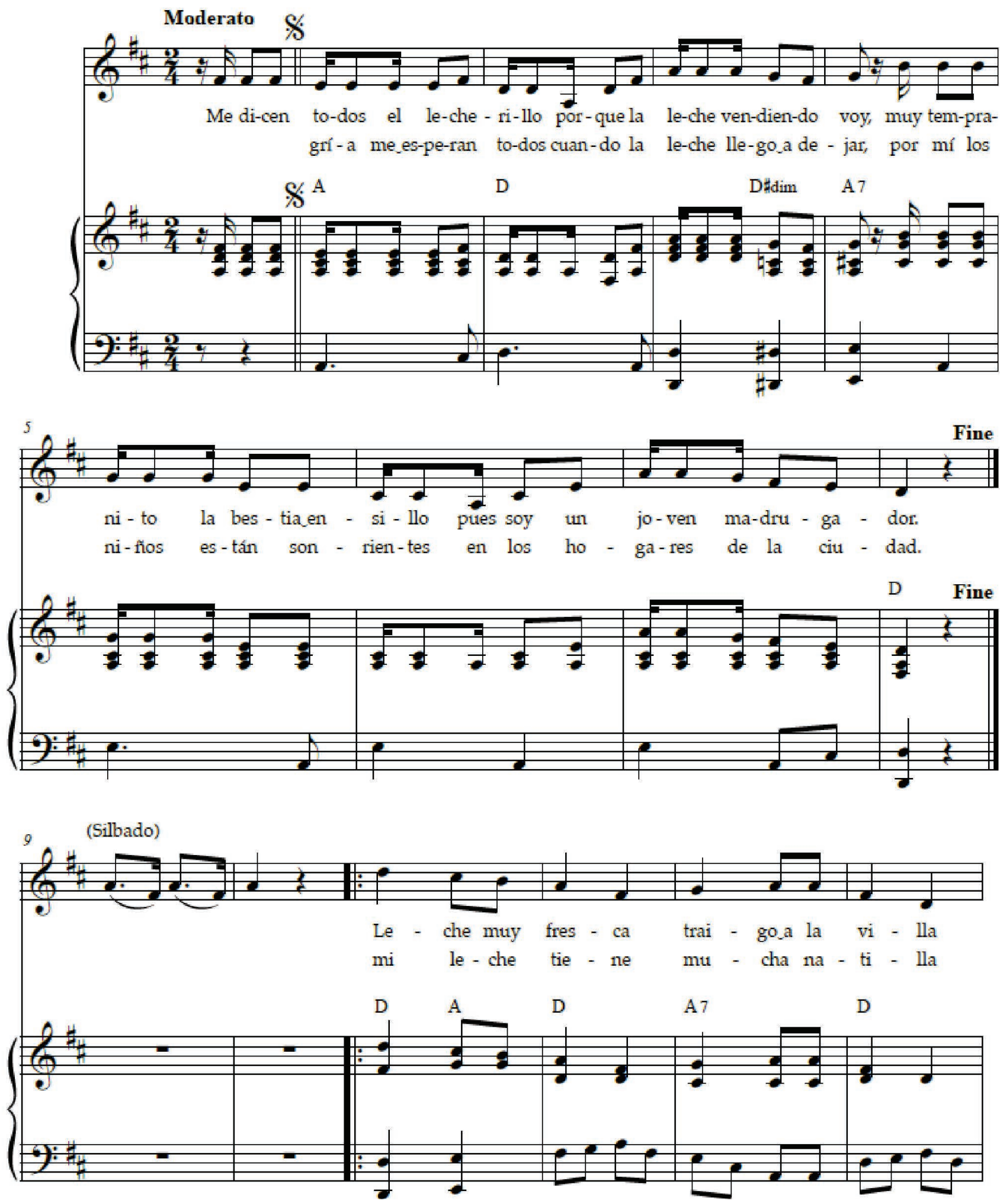

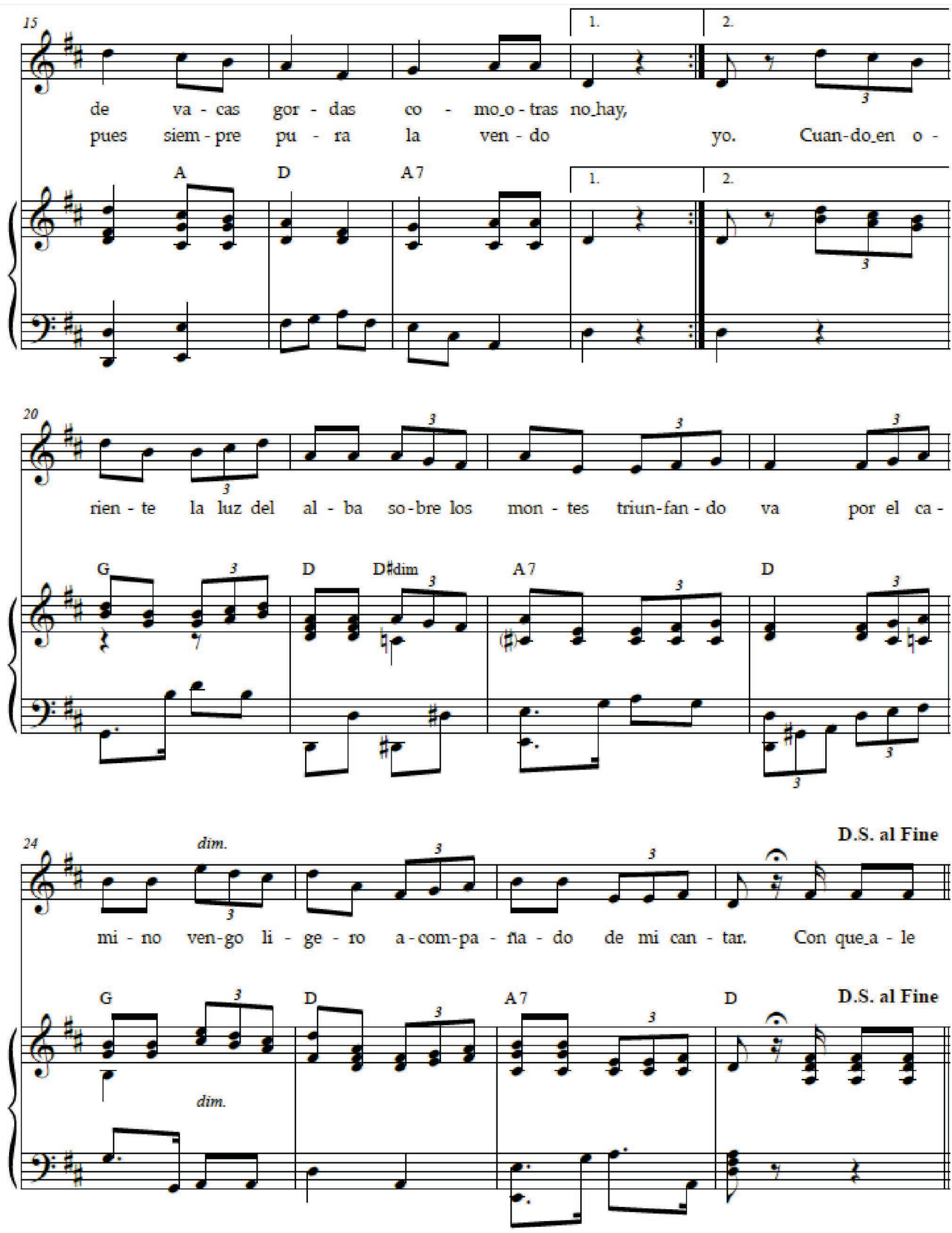

El lecherillo 


\section{Somos marineros}

Melodía y letra: Alcides Prado

Arreglo para piano: Katia Guevara Rojas

Edición: Jorge Eduardo Carmona Ruiz 2015.

Allegro con brio
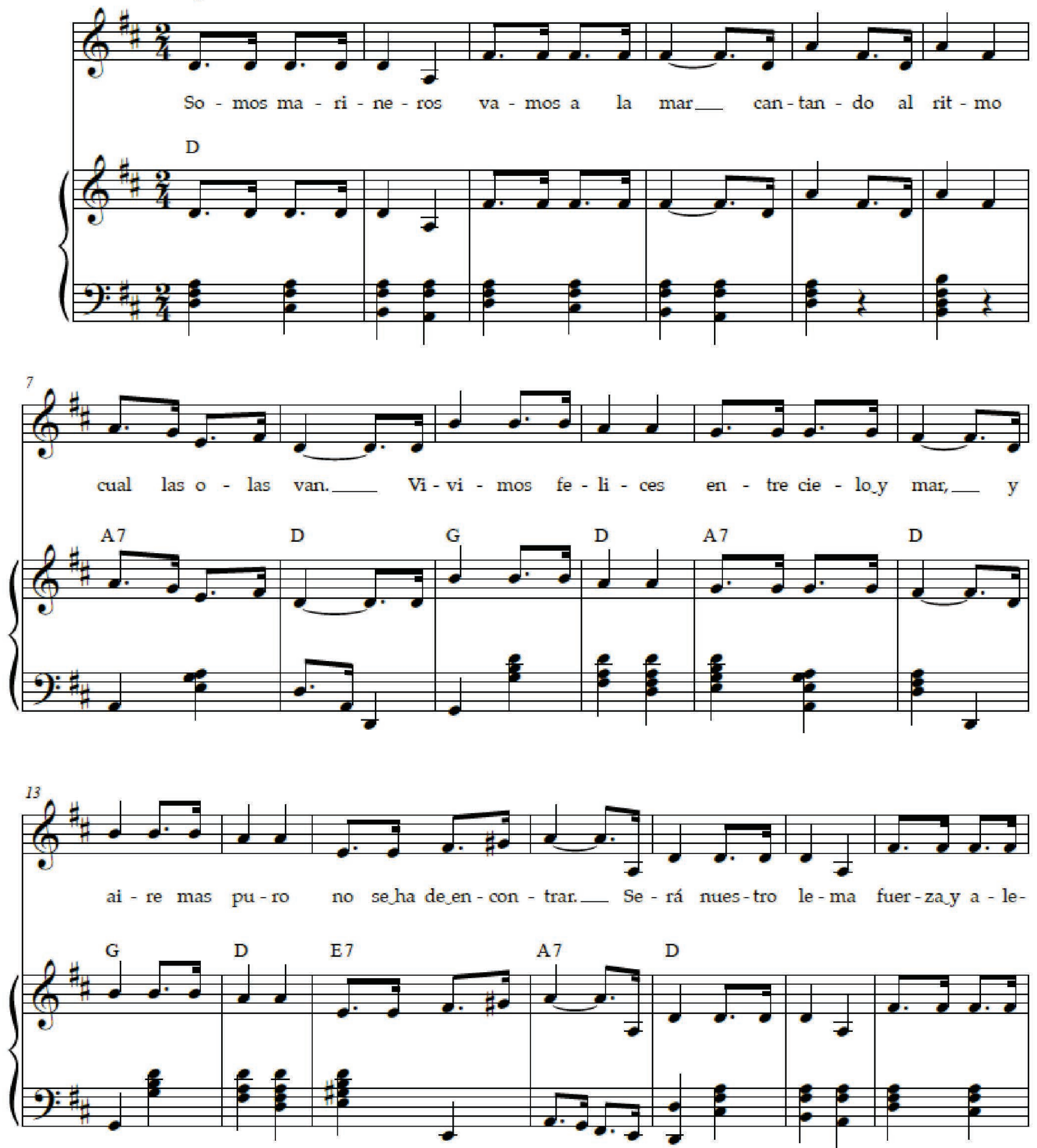


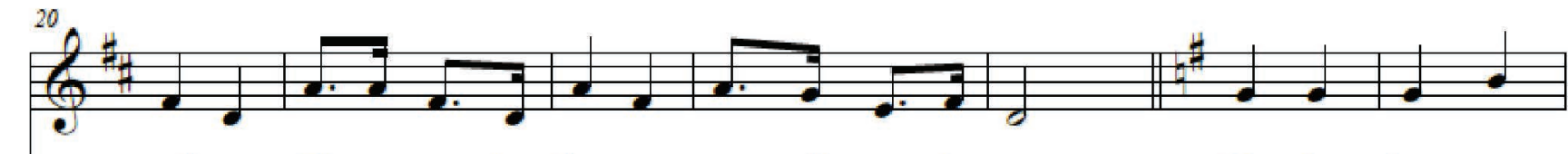
grí - a. Vi - va nues - tro bar-co que se.ha-ce_a la mar. Un, dos, tres... mar -
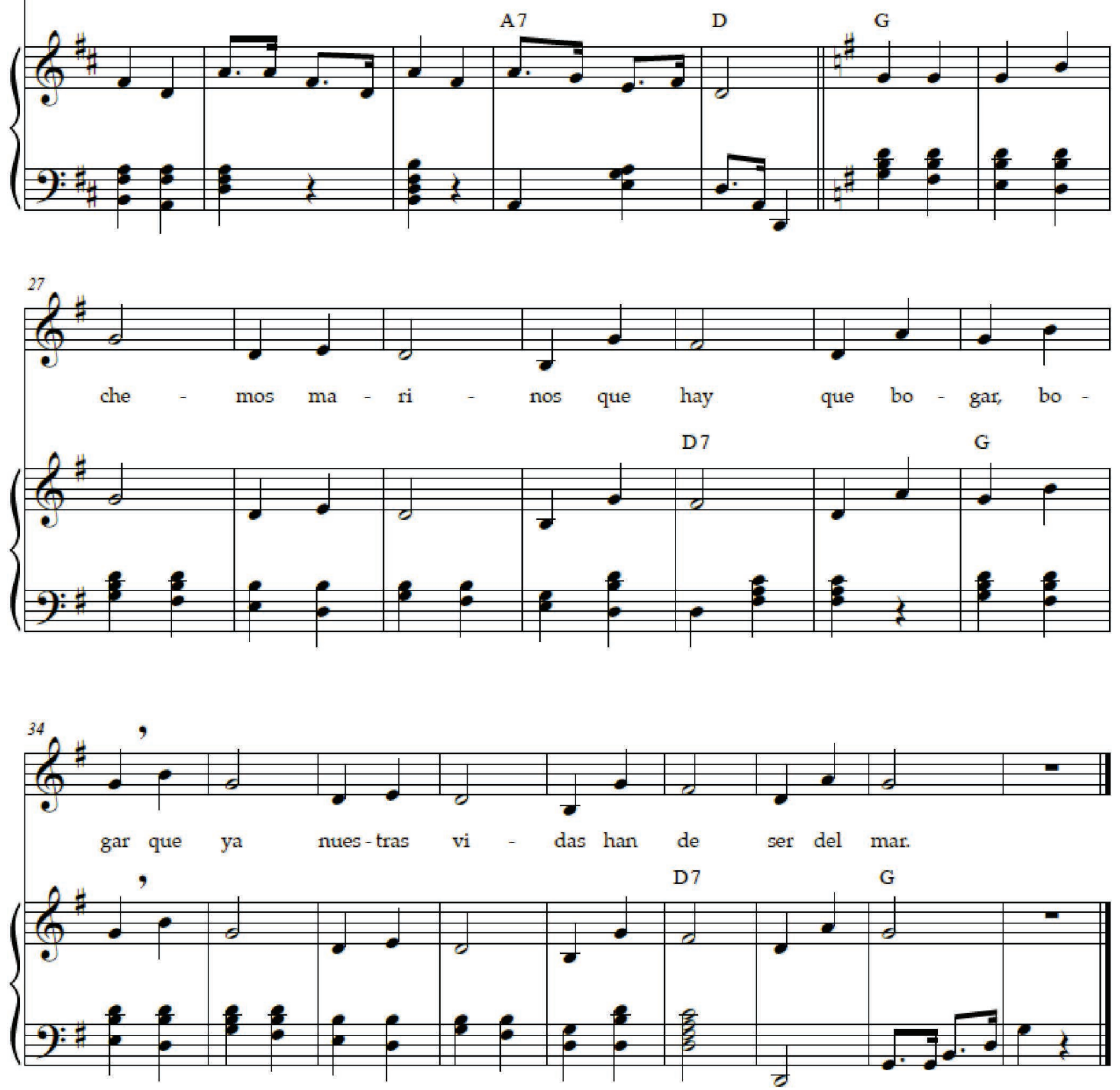
Santa y bella
Letra y música: Miguel Ángel Hidalgo S. Edición: Jorge Eduardo Carmona Ruiz 2015.

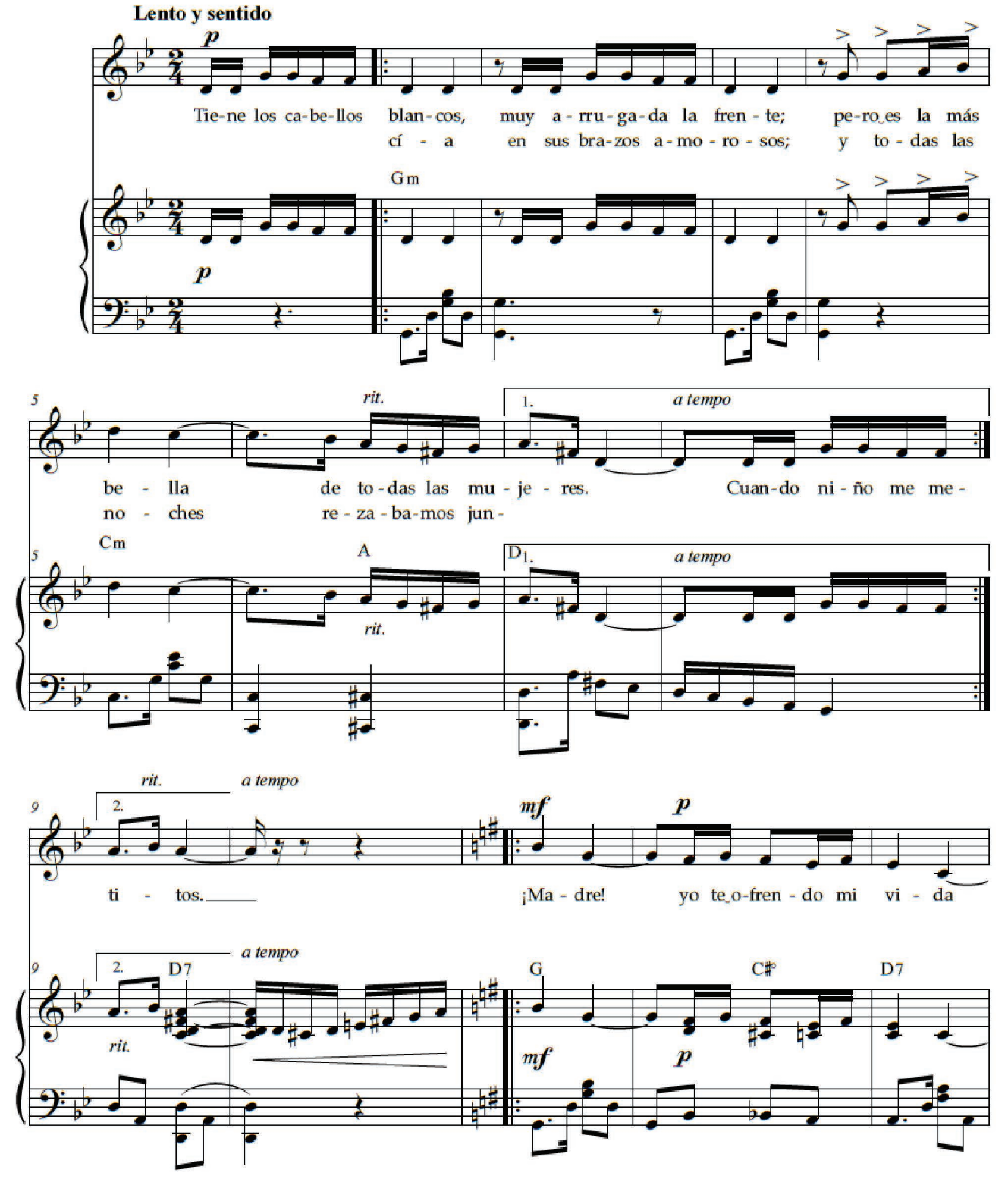



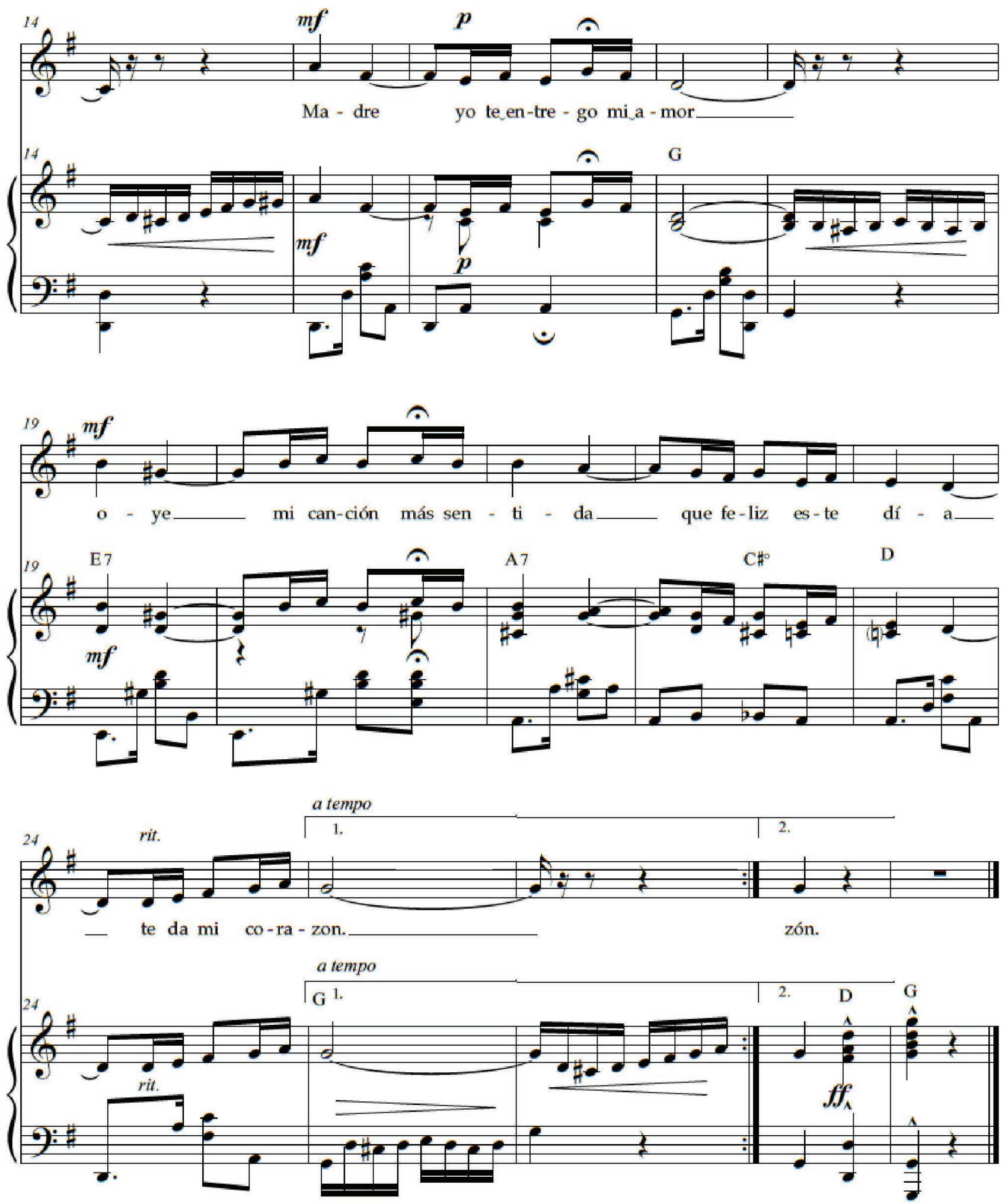

Santa y bella 


\section{En Puntarenas ${ }^{1}$}

Música: Roberto Campabadal Gorro Letra: Lisímaco Chavarría Palma Edición: Jorge Eduardo Carmona Ruiz 2015.
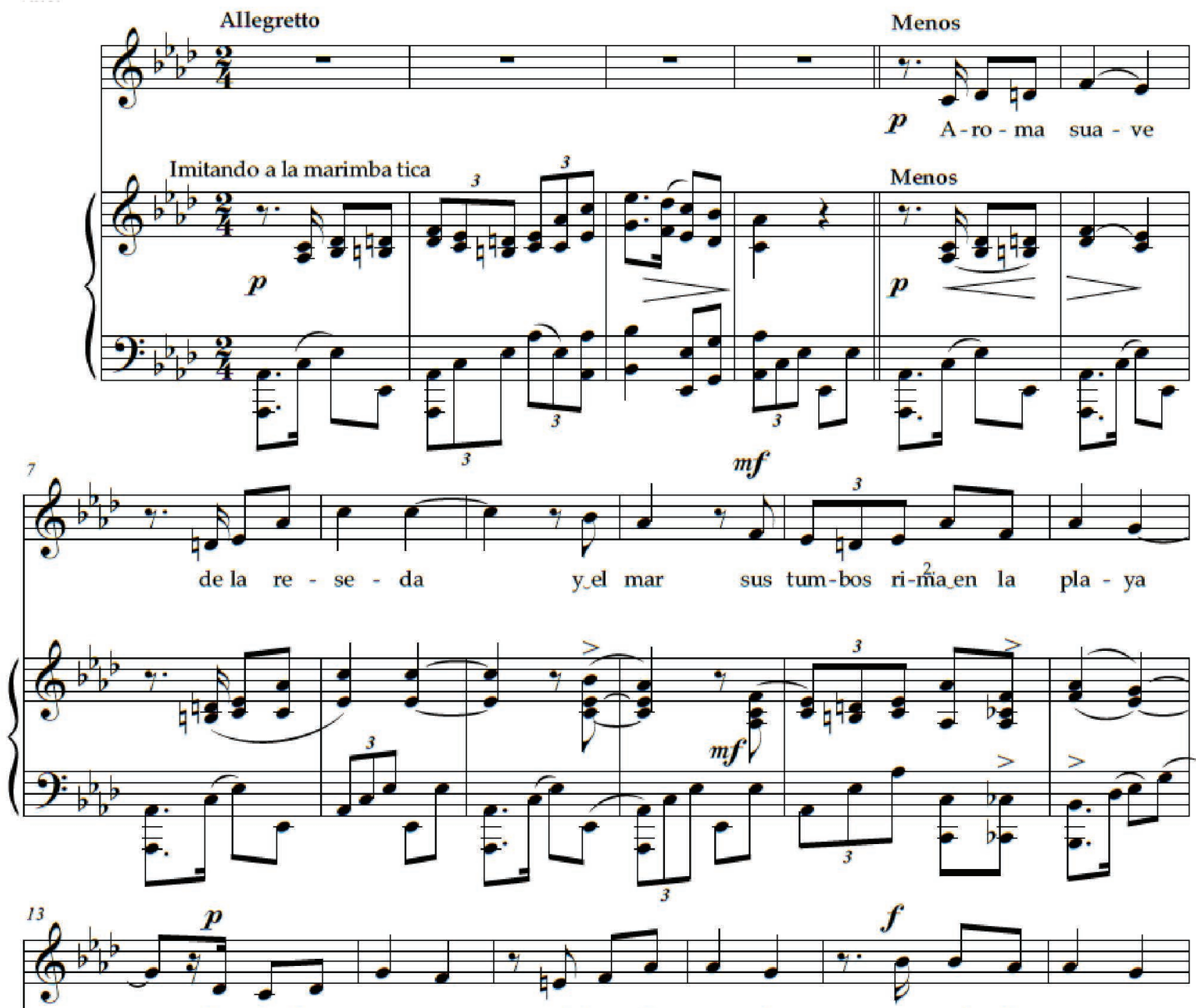
don-de laes - pu - ma vi-bran-do que - da co-mohe-lio - tro - po,

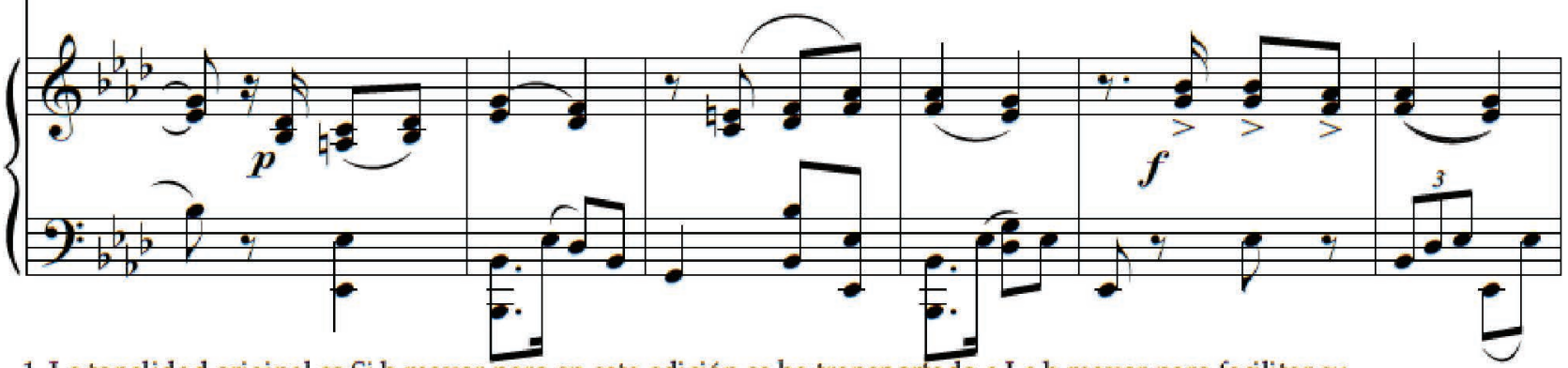

1. La tonalidad original es Si b mayor pero en esta edición se ha transportado a La b mayor para facilitar su interpretación por un mayor número de personas.

2. En el libro Época de oro de la canción escolar costarricense aparece la palabra "alma", sin embargo, hemos utilizado el verbo "rima", ya que es así como aparece en el poema original. (Rodríguez, 2013:452) 


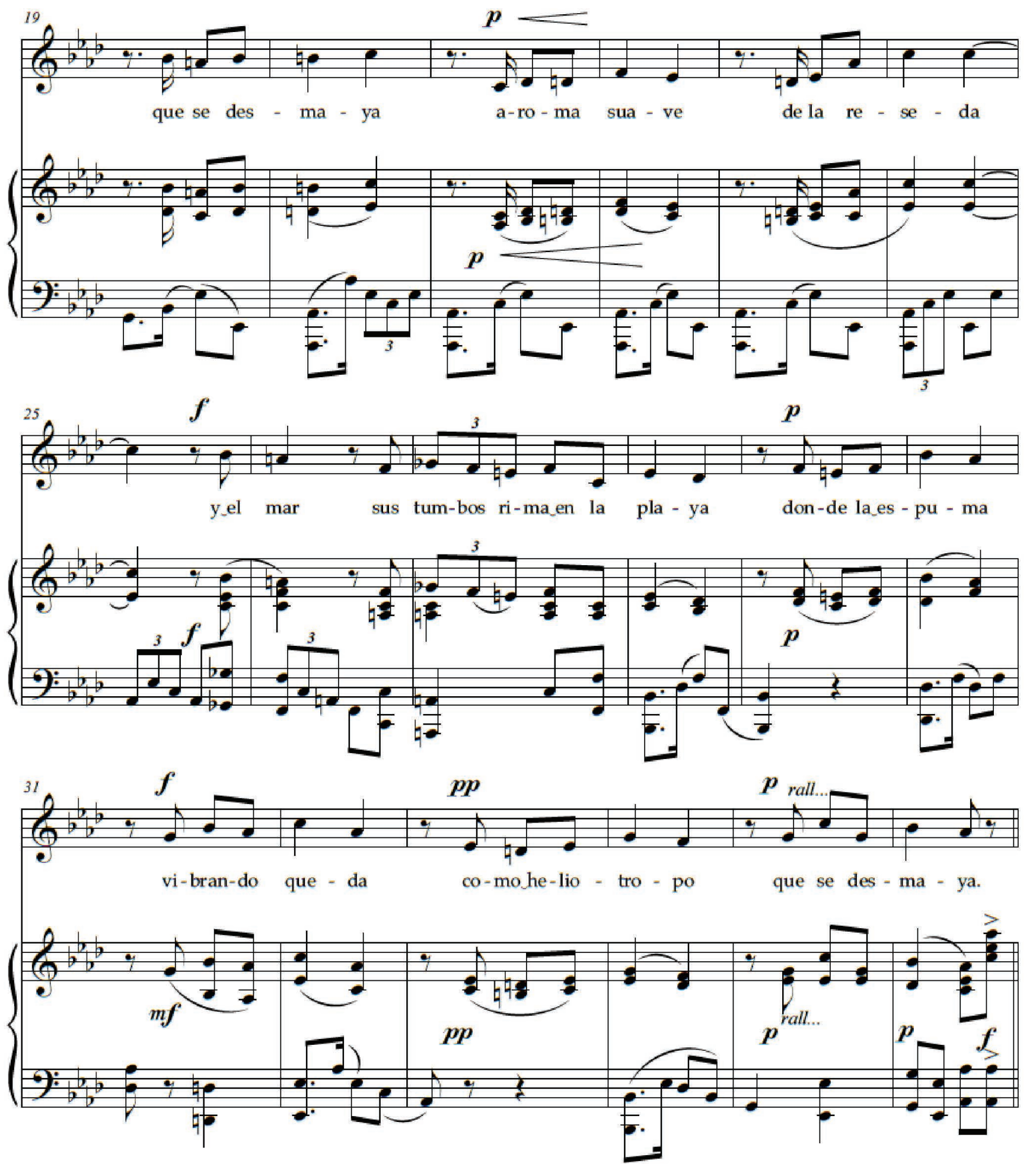

En Puntarenas 

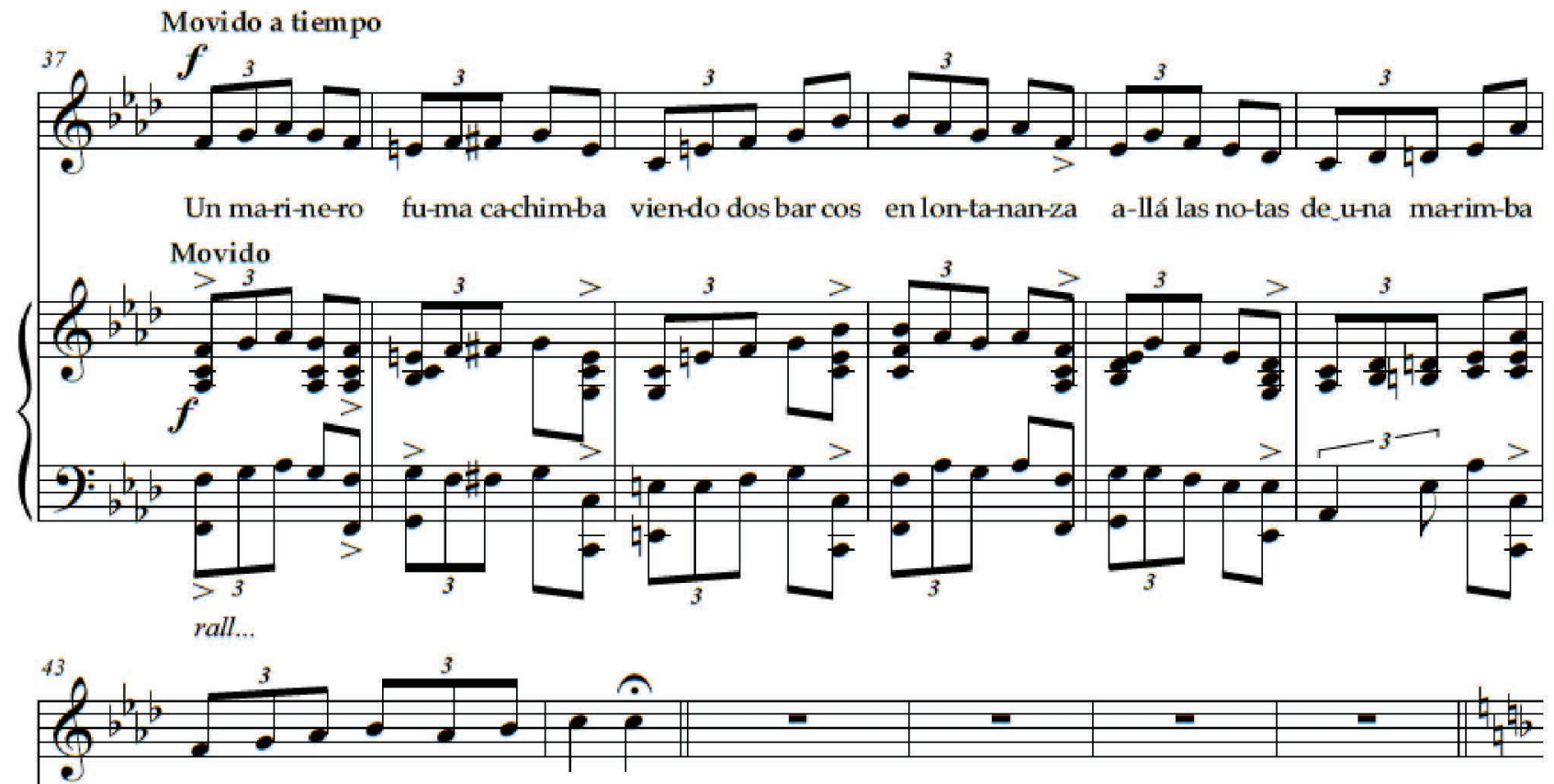

se u-nen ri-man-do,u-na dan-za.

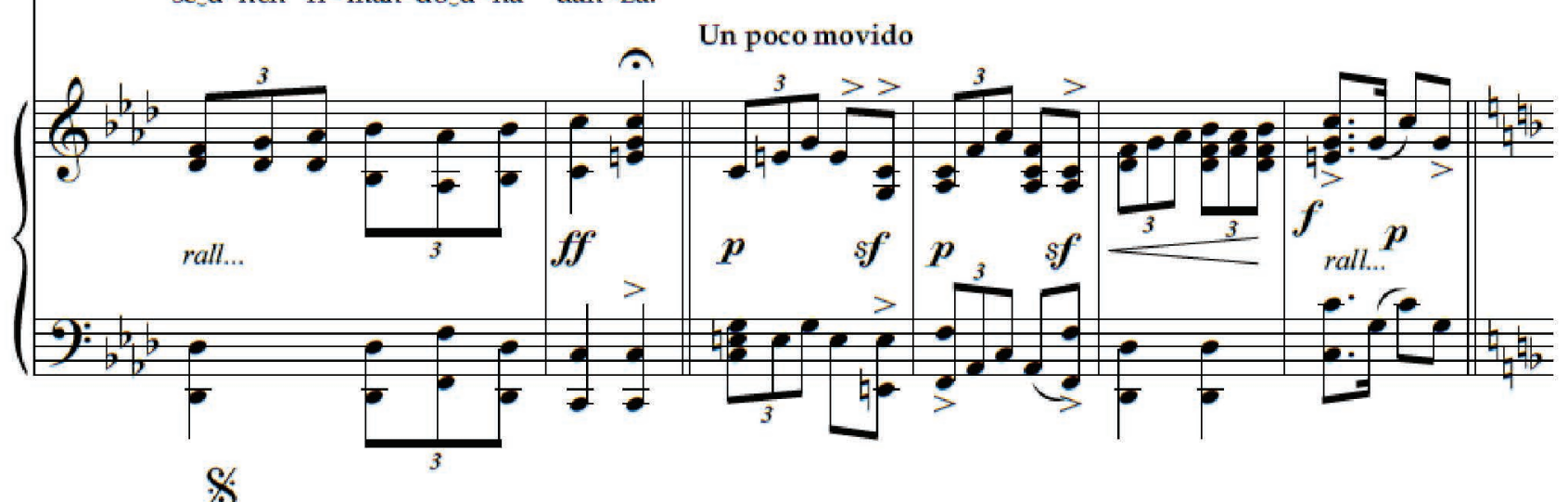

Moderato dolce

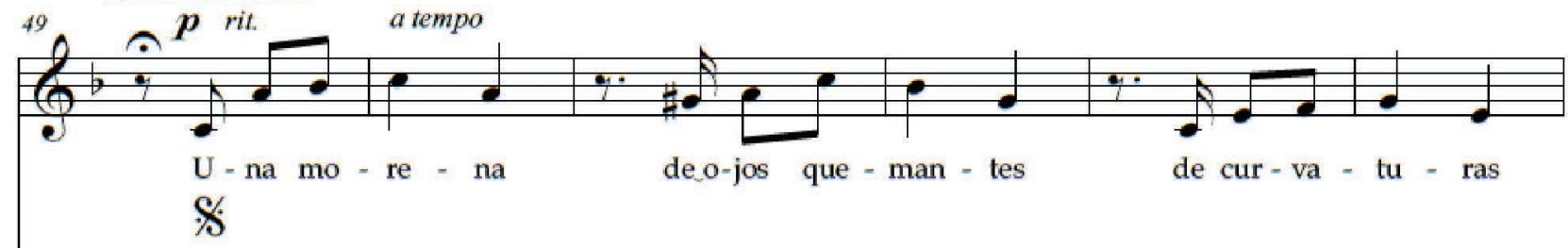

Moderato dolce a tempo

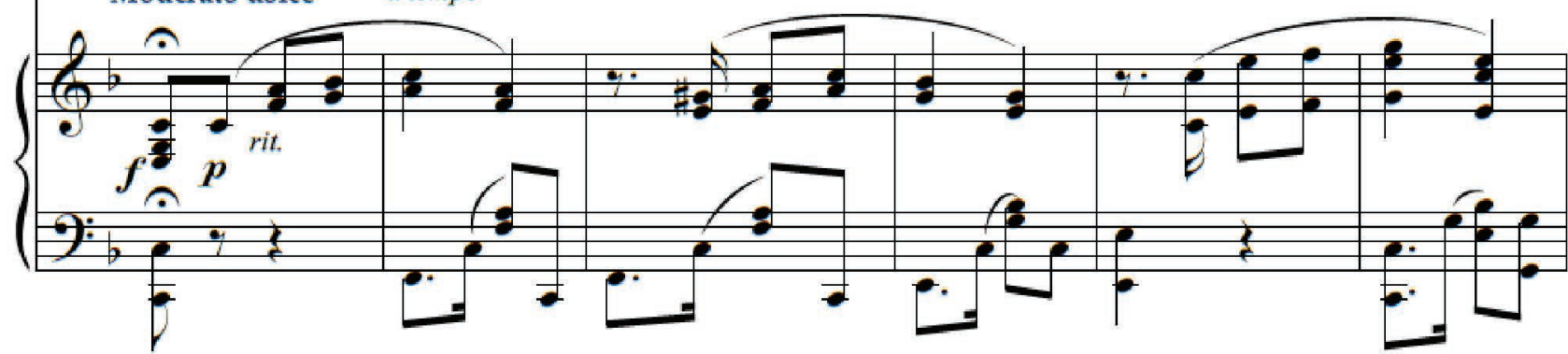

En Puntarenas 

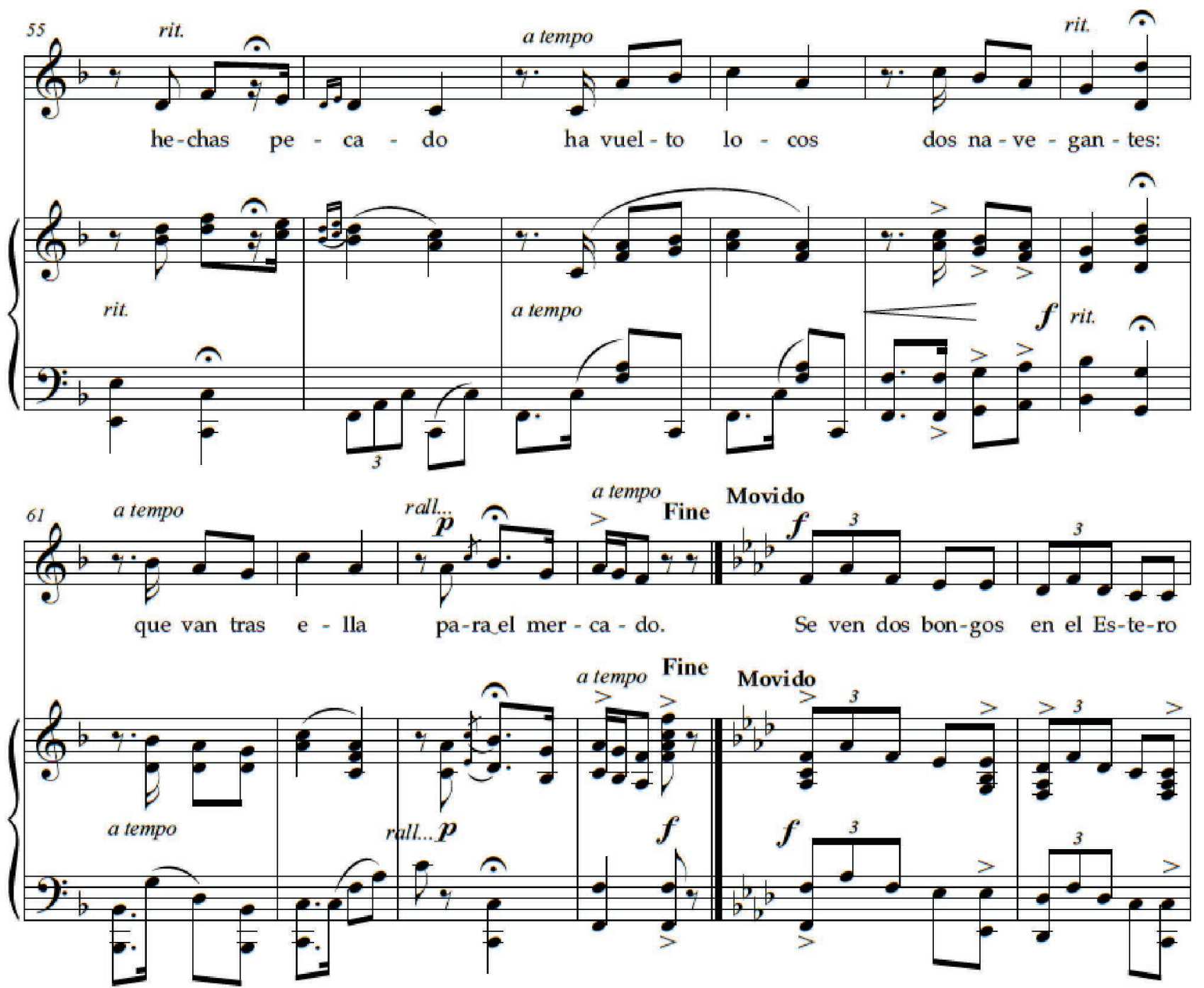

D.S. al Fine

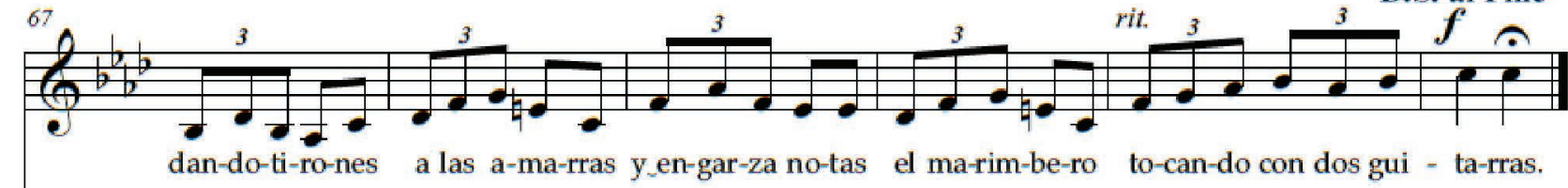

D.S. al Fine

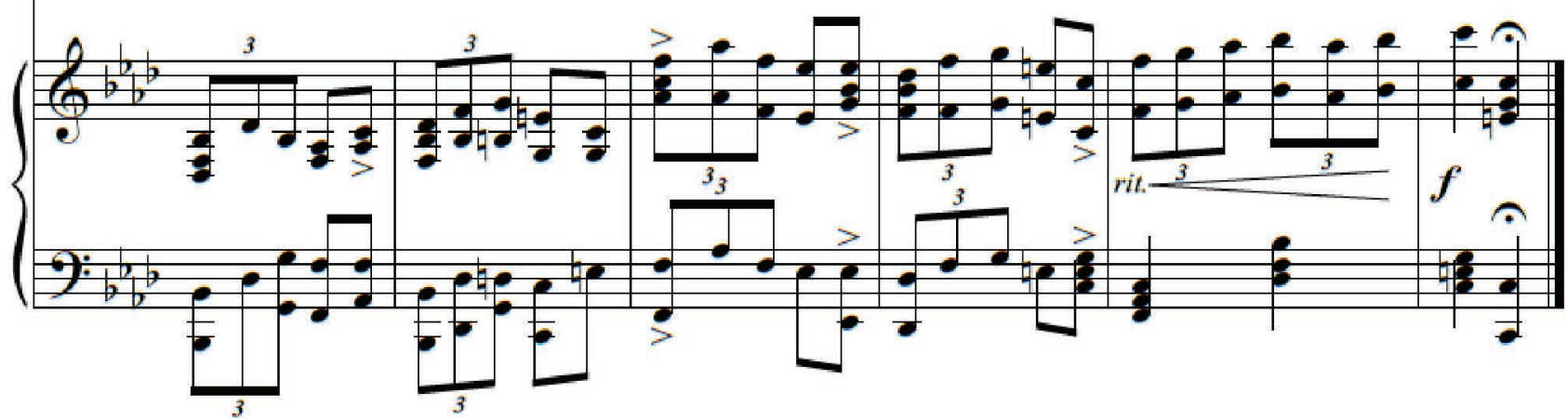

En Puntarenas 


\section{Golfito}

Melodía: José Daniel Zúñiga Z.

Letra: Edwin Salas B.

Arreglo para piano: Katia Guevara Rojas. Edición: Jorge Eduardo Carmona Ruiz 2015.
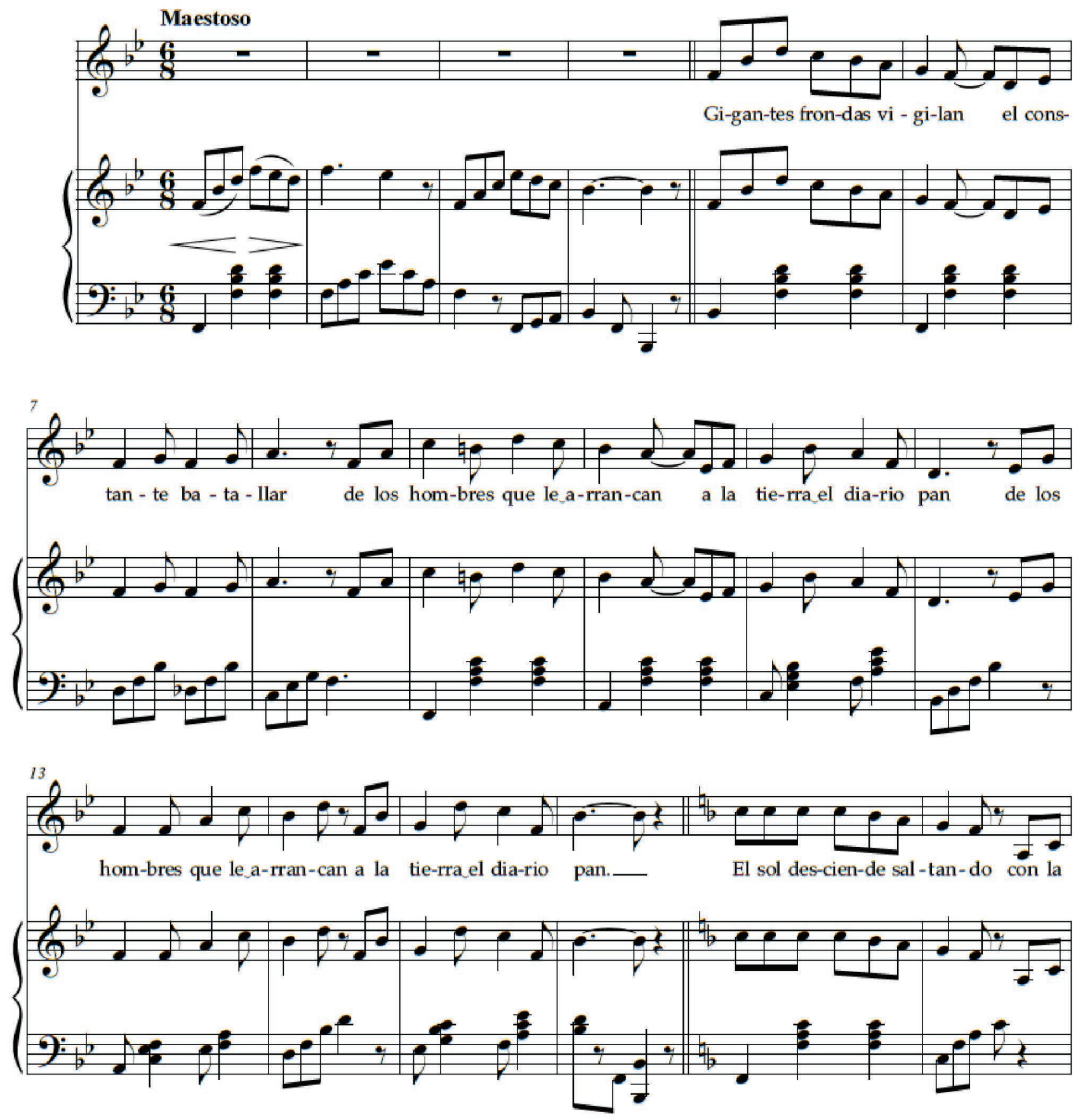

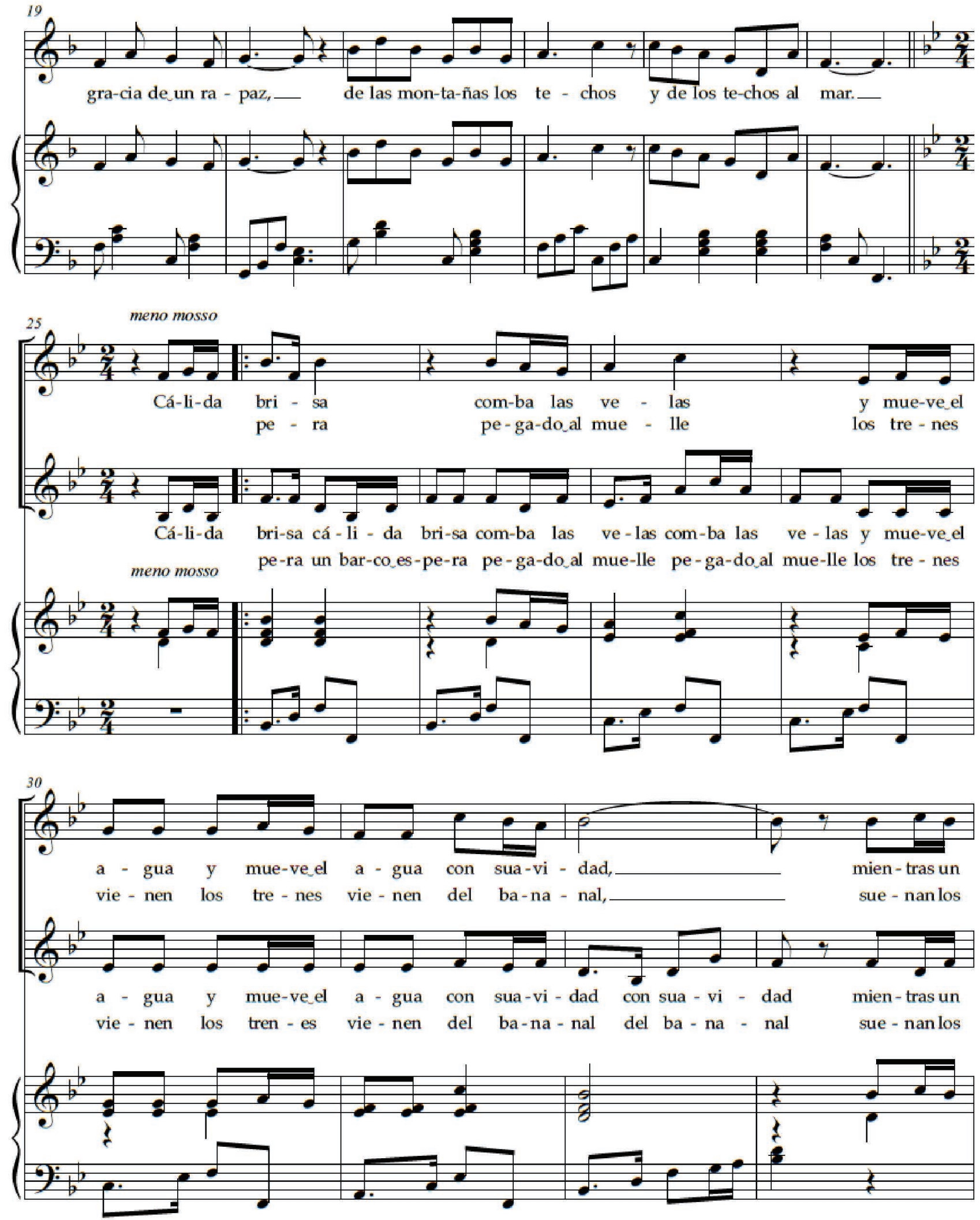

Golfito 

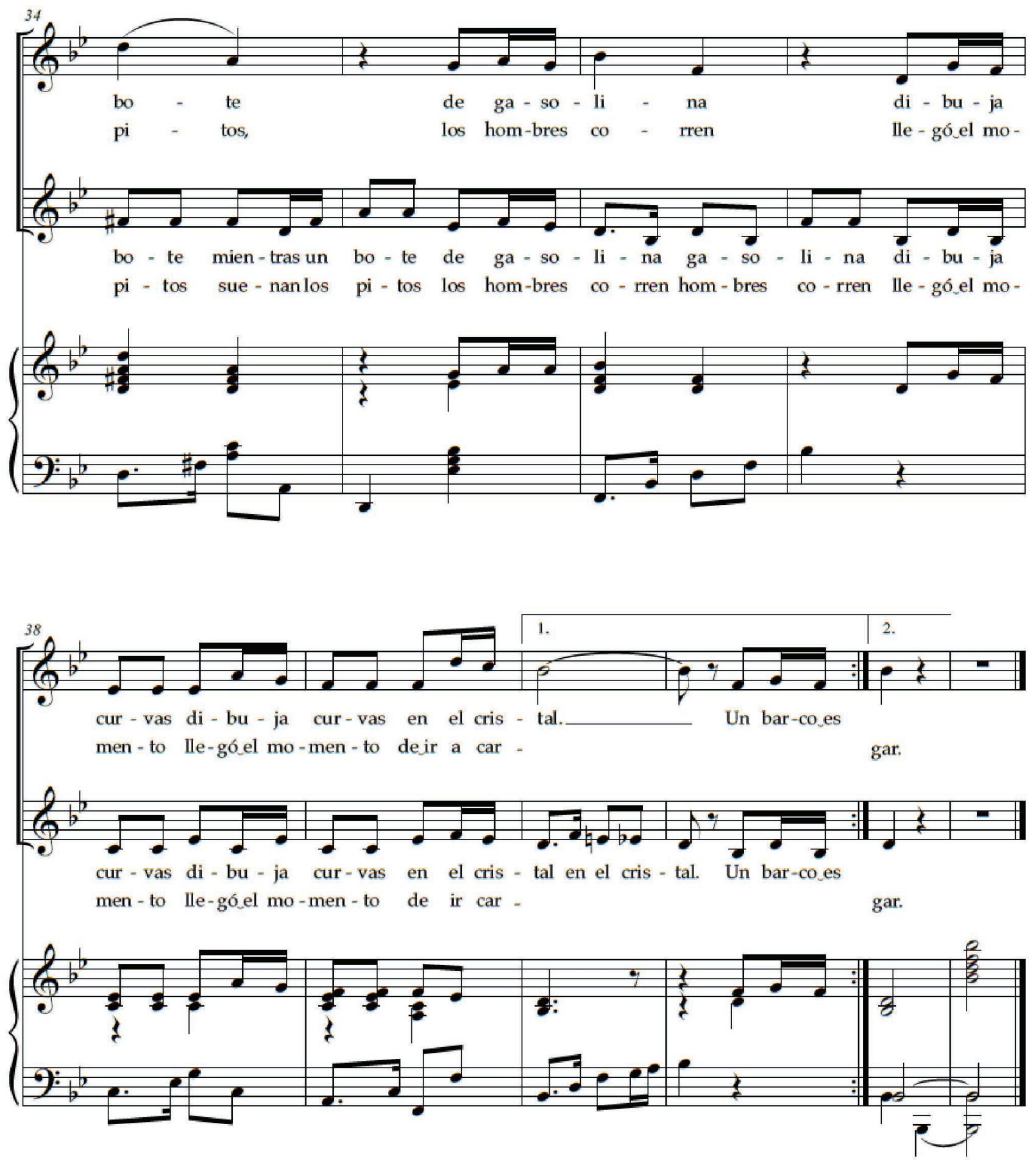

Golfito 
¡Oh, Costa Rica!
Música: Julio Fonseca Gutierrez

Letra: José Joaquín Salas Pérez

Edición: Jorge Eduardo Carmona Ruiz 2015.
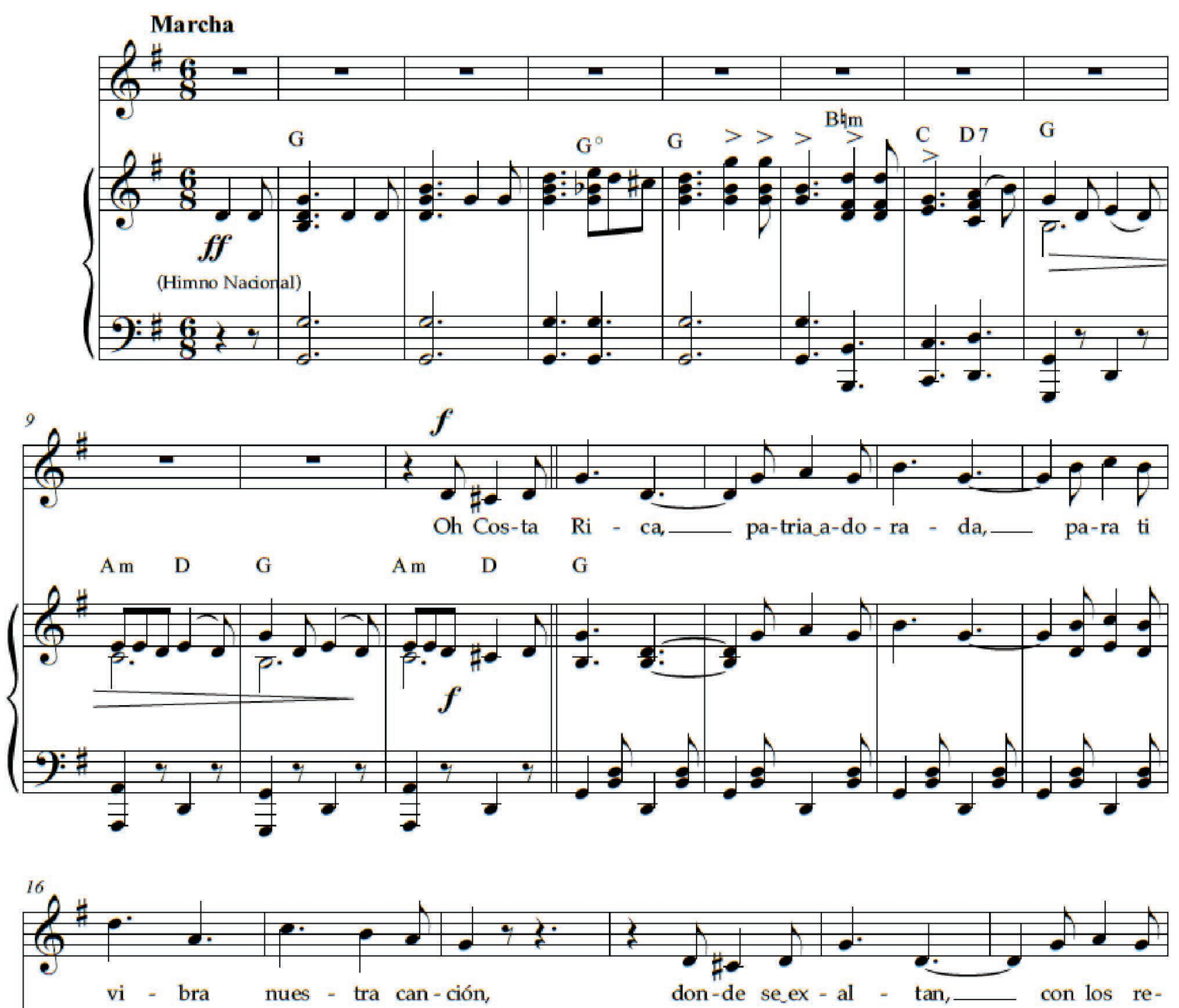

7

G

Am $\quad$ D

G

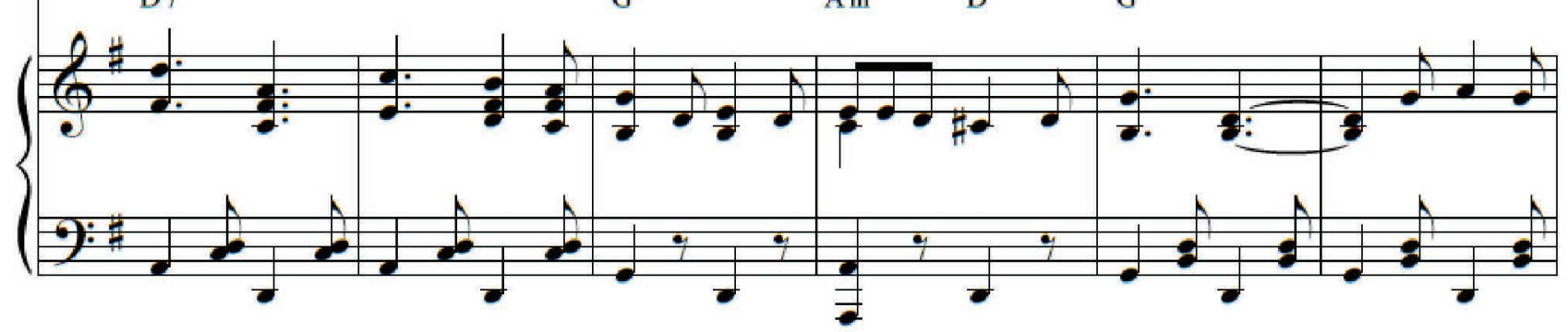

1. En el libro Época de oro de la canción costarricense tiene como subtítulo "Marcha premiada". (Camacho y Quesada, 2004: 282) 

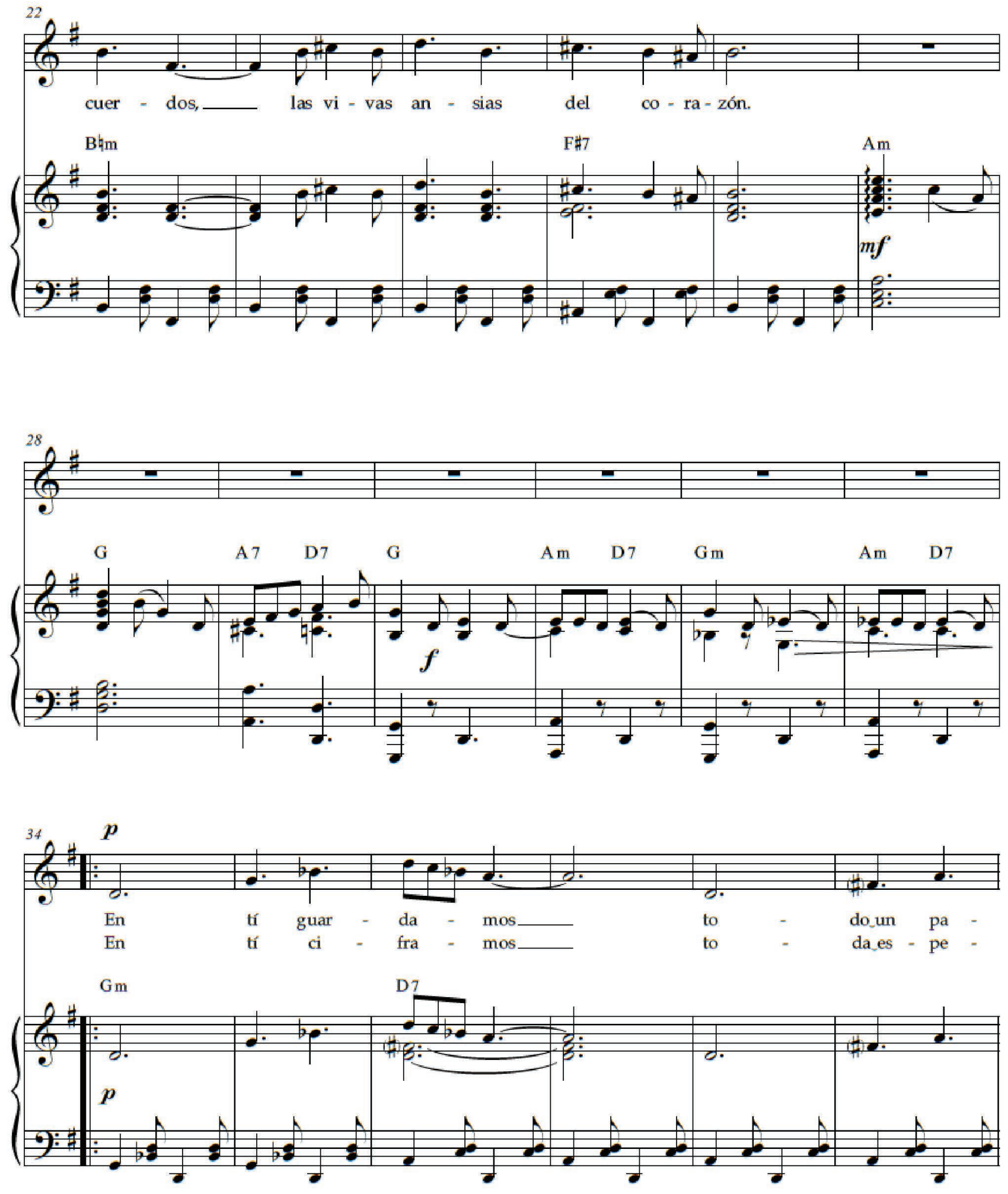

¡Oh, Costa Rica! 

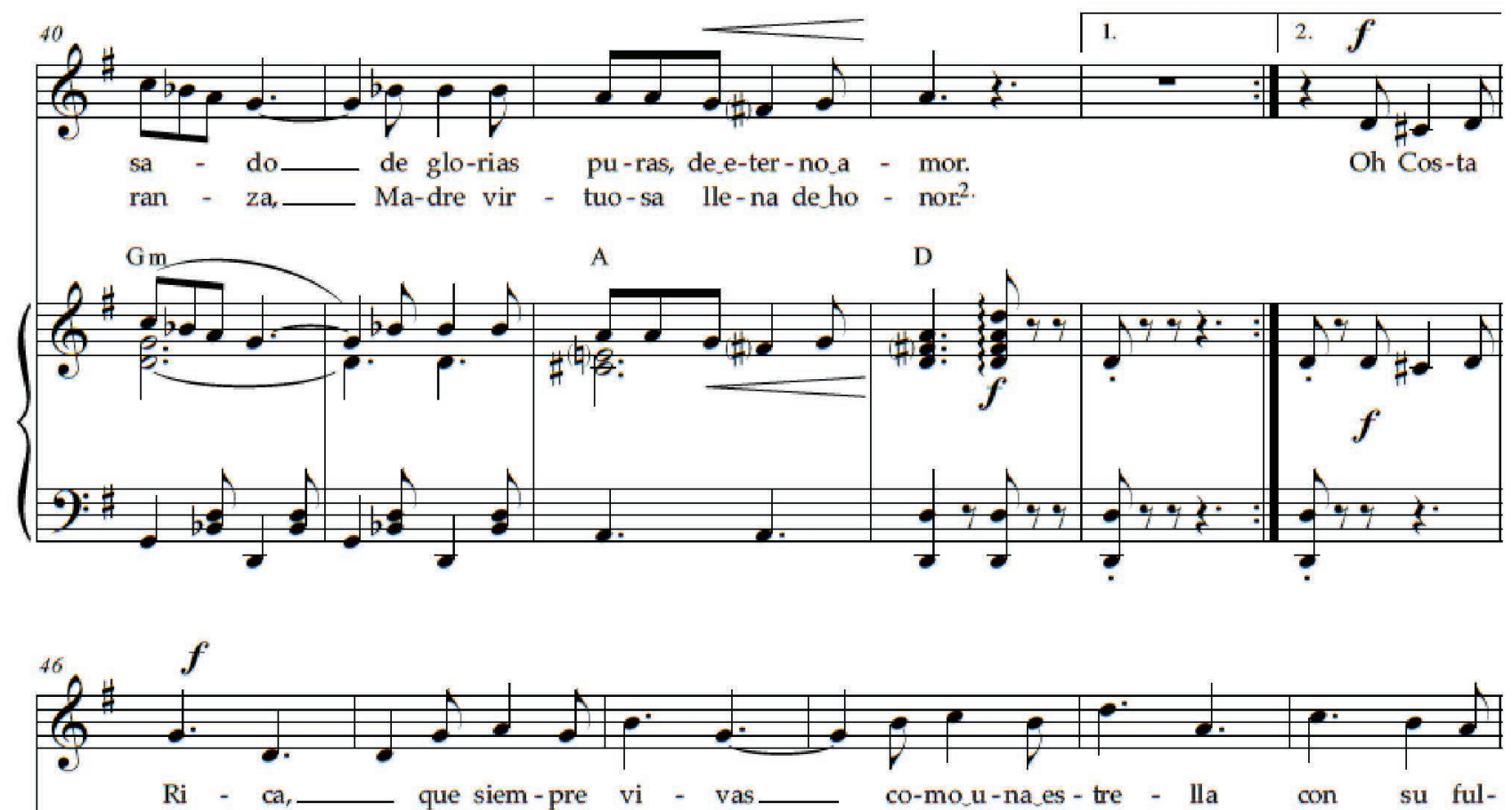

G $\quad$ D7
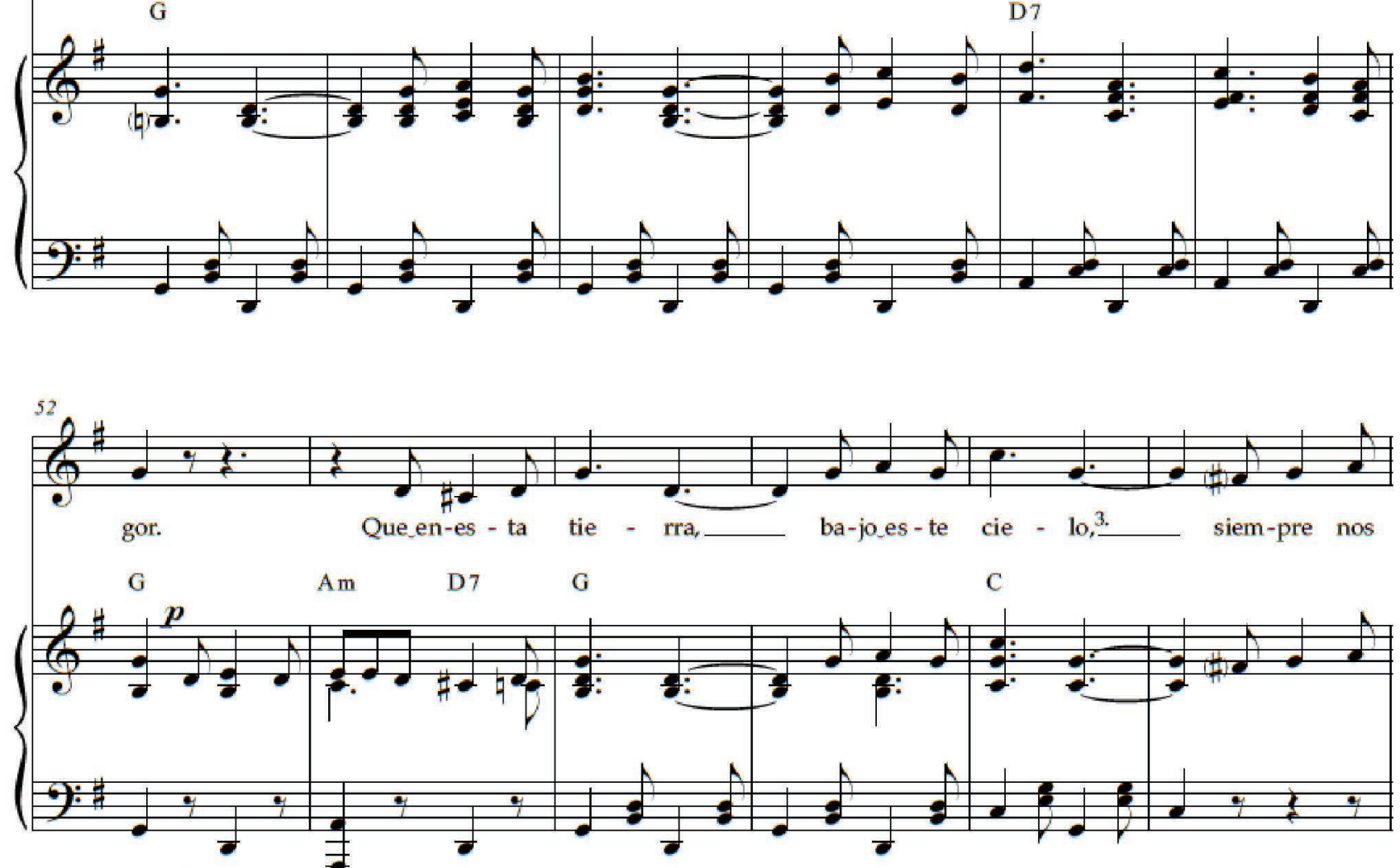

2. En el libro Épora de oro de la canción escolar costarricense aparece la palabra "amor", sin embargo, en otras fuentes aparece la palabra "honor".

3. En el libro Época de or de la canción costarricense aparece la palabra "suelo". Sin embargo, cotejando otras fuentes y por lógica, debe ser la palabra "cielo". (Zủñiga, 1976:39; Zúñiga, 1980:122)

¡Oh, Costa Rica! 

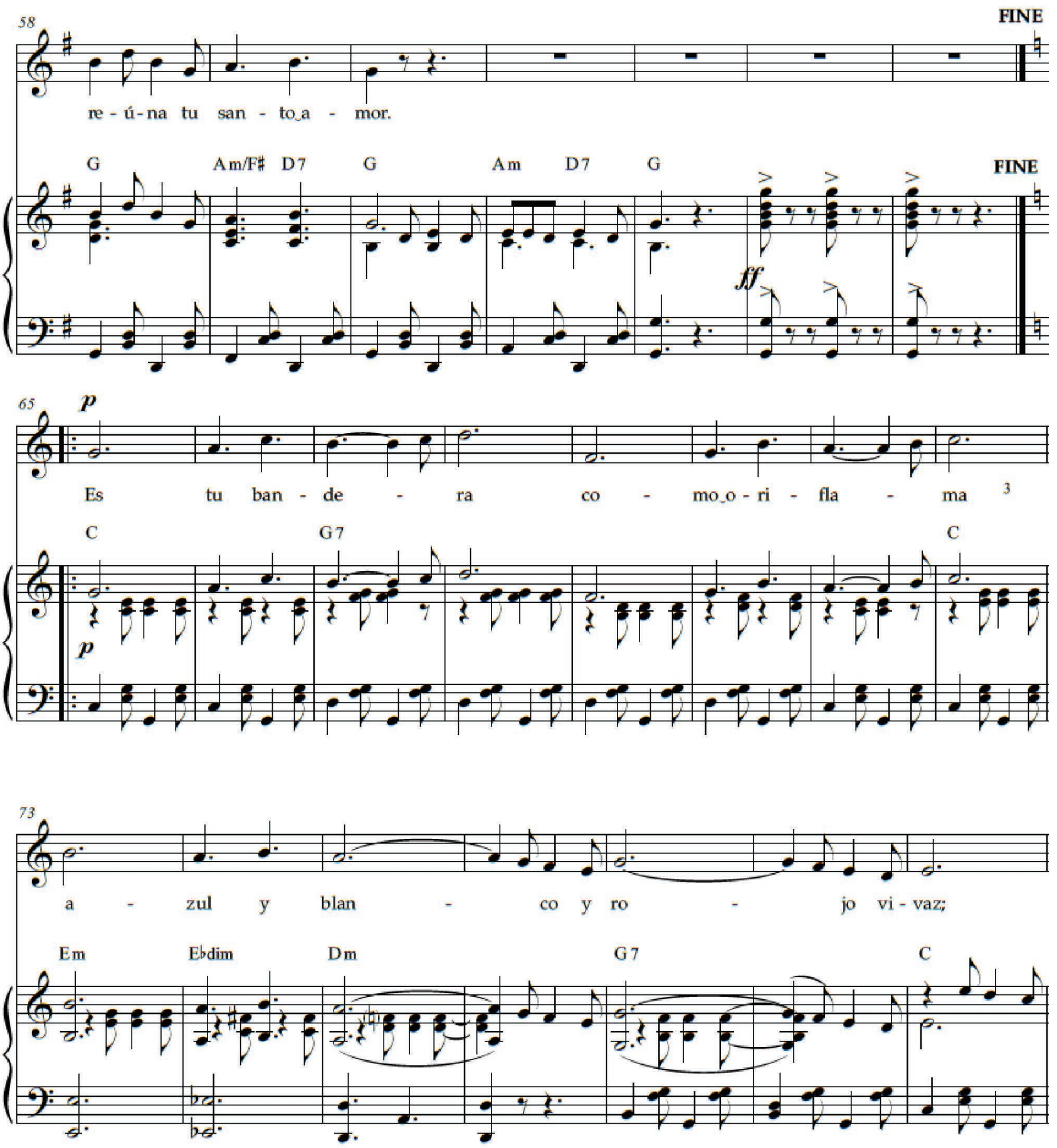

3. En el libro Época de oro de la canción costarricense aparecen las palabras "oro y flama", sin embargo, en otras fuentes consultadas aparece "oriflama" como se utiliza aquí. (Zúñiga, 1976:39; Zúñiga, 1980:122)

¡Oh, Costa Rica! 

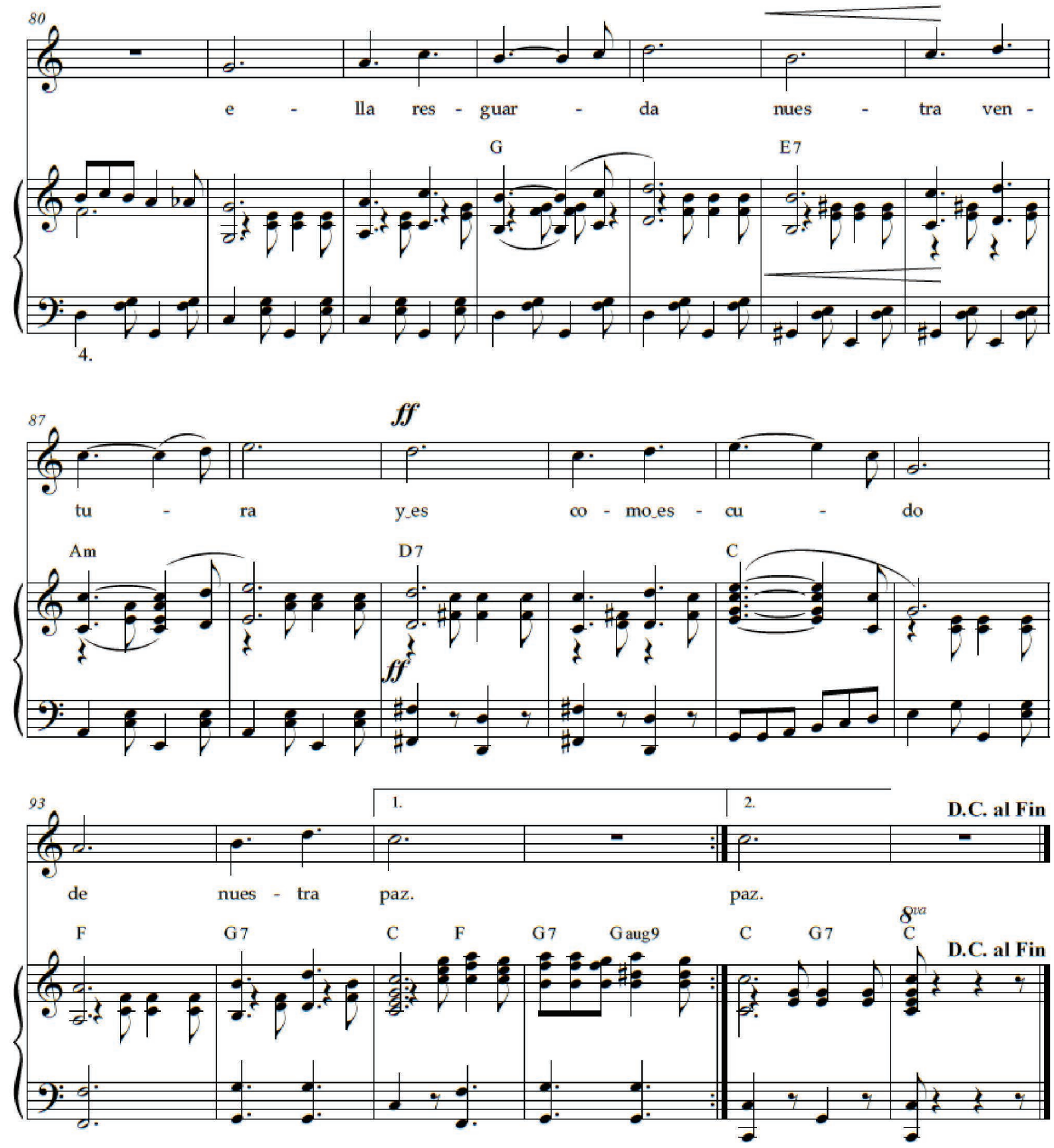

4. En otras ediciones se mantiene el acorde de tónica en el acompañamiento.

¡Oh, Costa Rica! 


\section{Casita en que nací ${ }^{1}$}

Música: José Joaquín Ureña Morales Letra: Carlomagno Araya Edición: Jorge Eduardo Carmona Ruiz 2015.
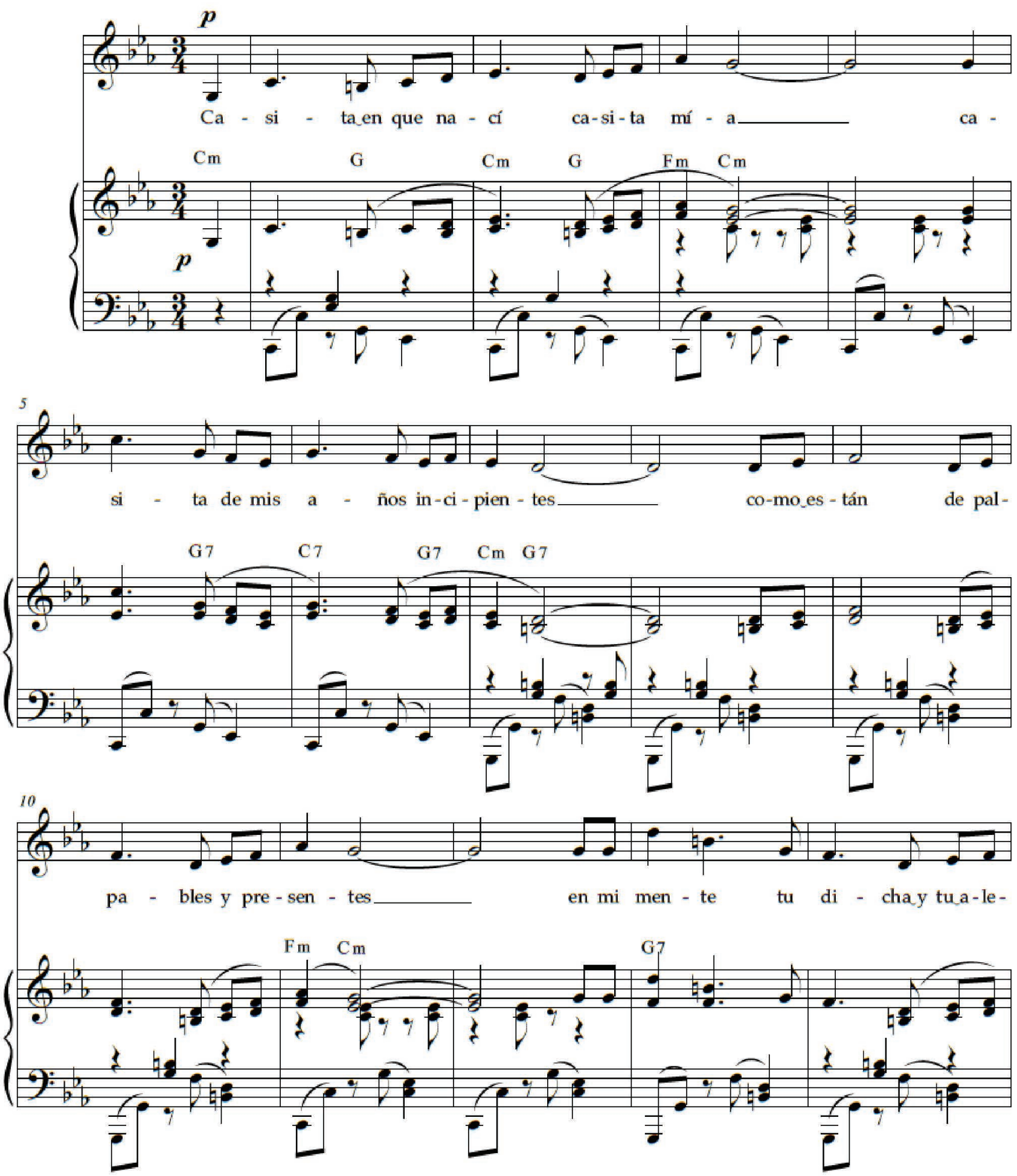

1. La tonalidad original es Re menor pero se ha transportado a Do menor para facilitar su interpretación por un mayor número de personas. 

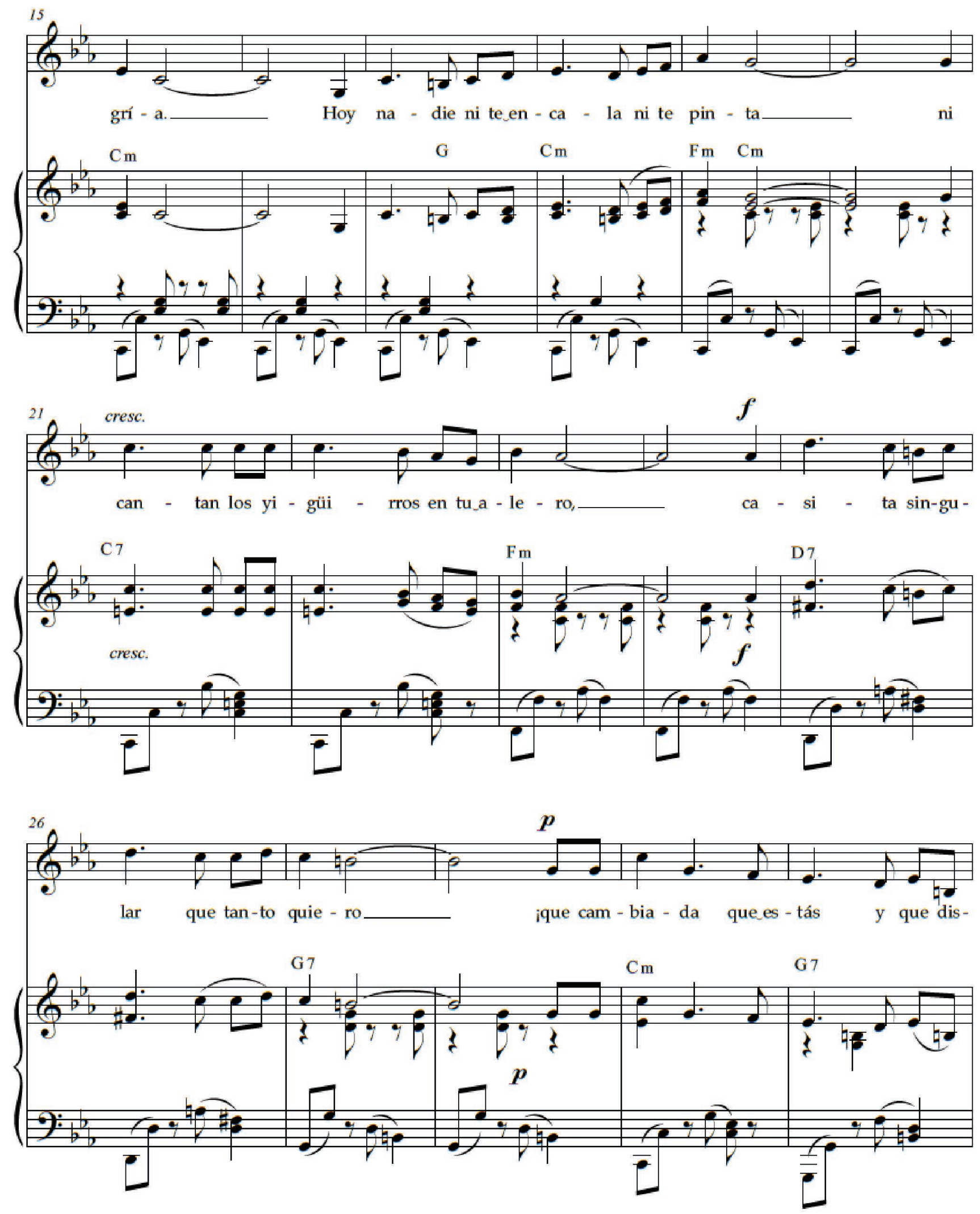

Casita en que nací 

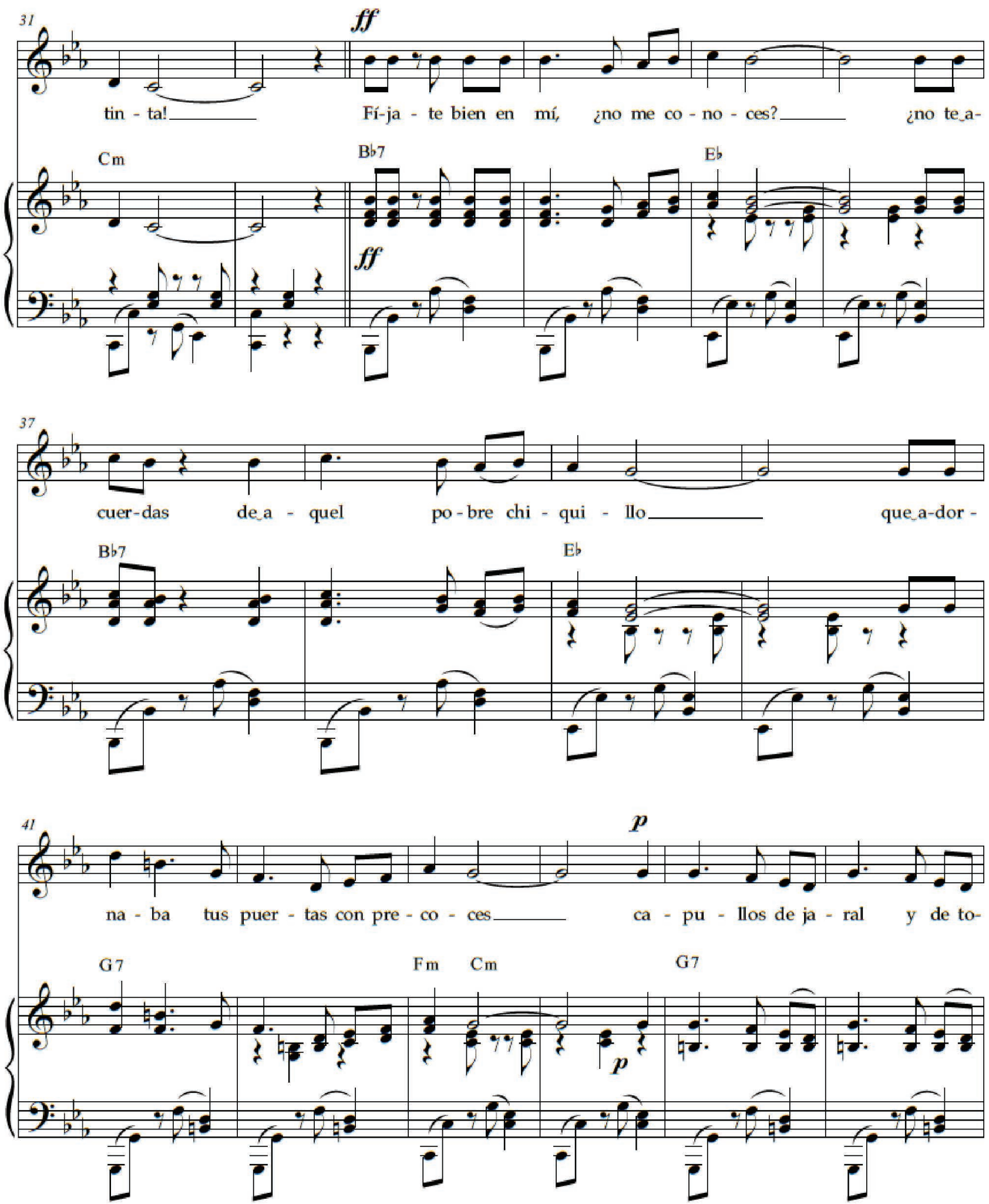

Casita en que nací 
64

- Revista Pensamiento Actual - Vol 16 - No. 27, 2016 - Universidad de Costa Rica - Sede de Occidente.
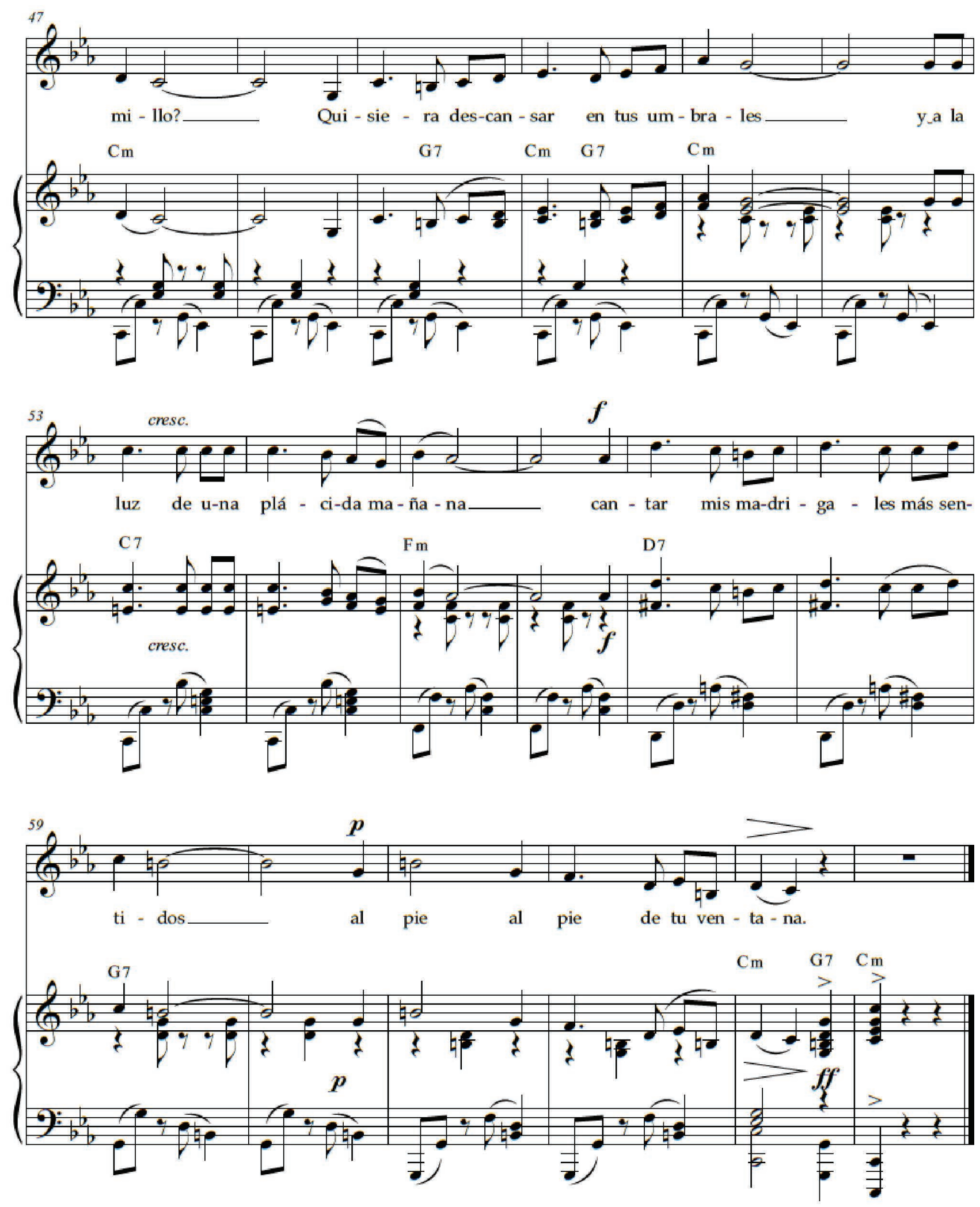

Casita en que nací 


\section{Caña dulce}

Música: José Daniel Zúñiga Zeledón Letra: José Joaquín Salas Pérez

Edición: Jorge Eduardo Carmona Ruiz 2015.

Moderato
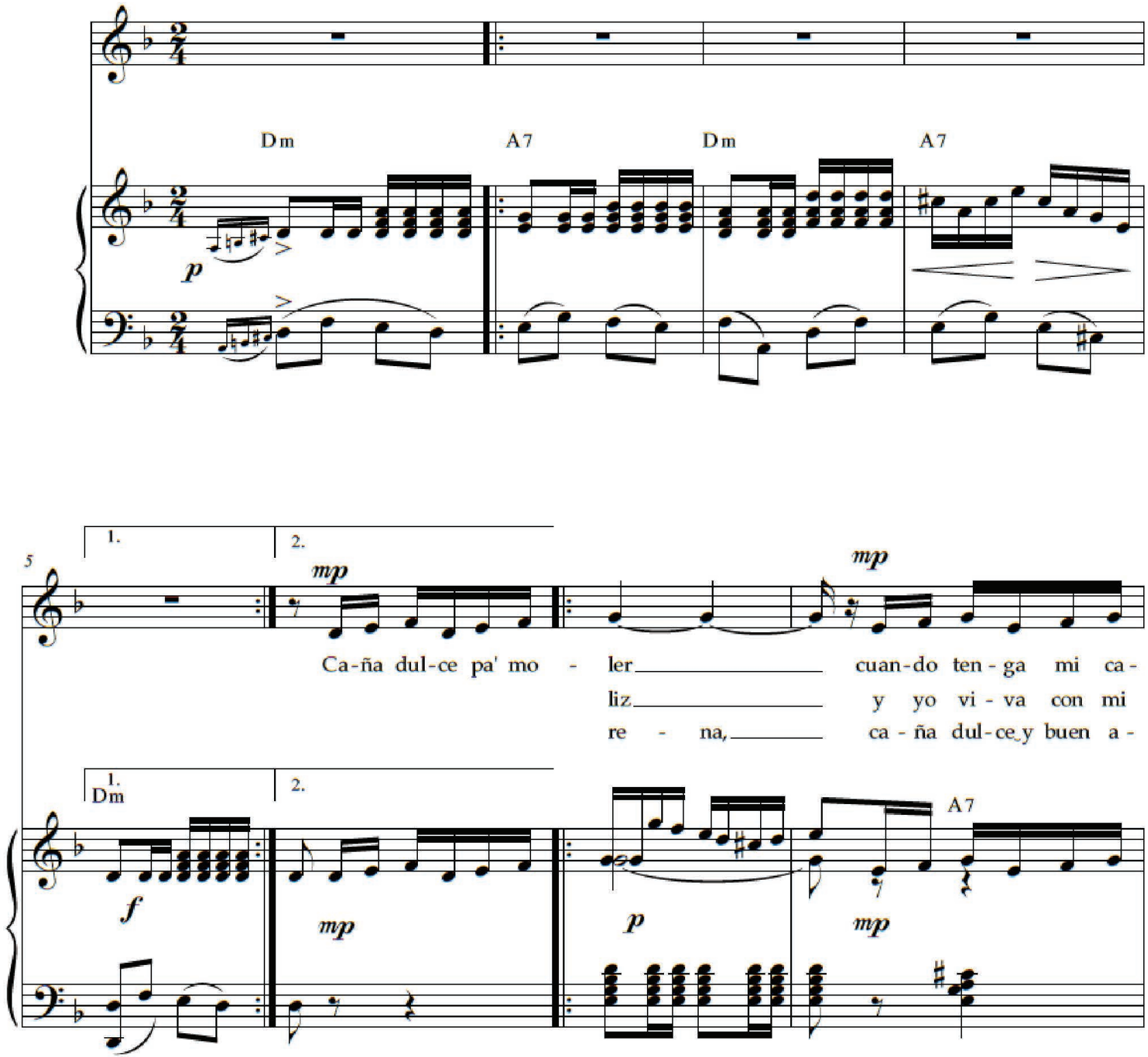

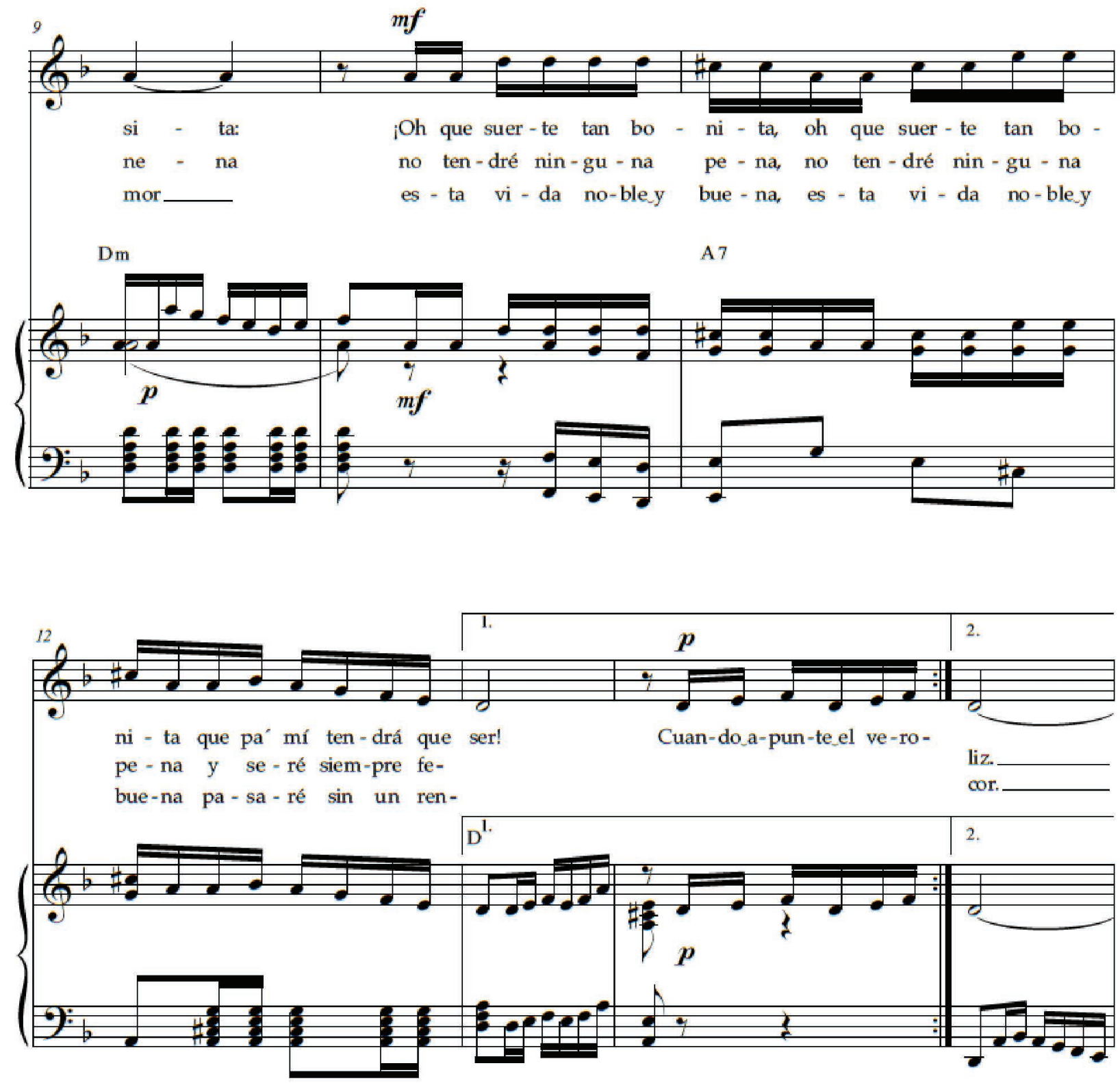

Caña dulce 

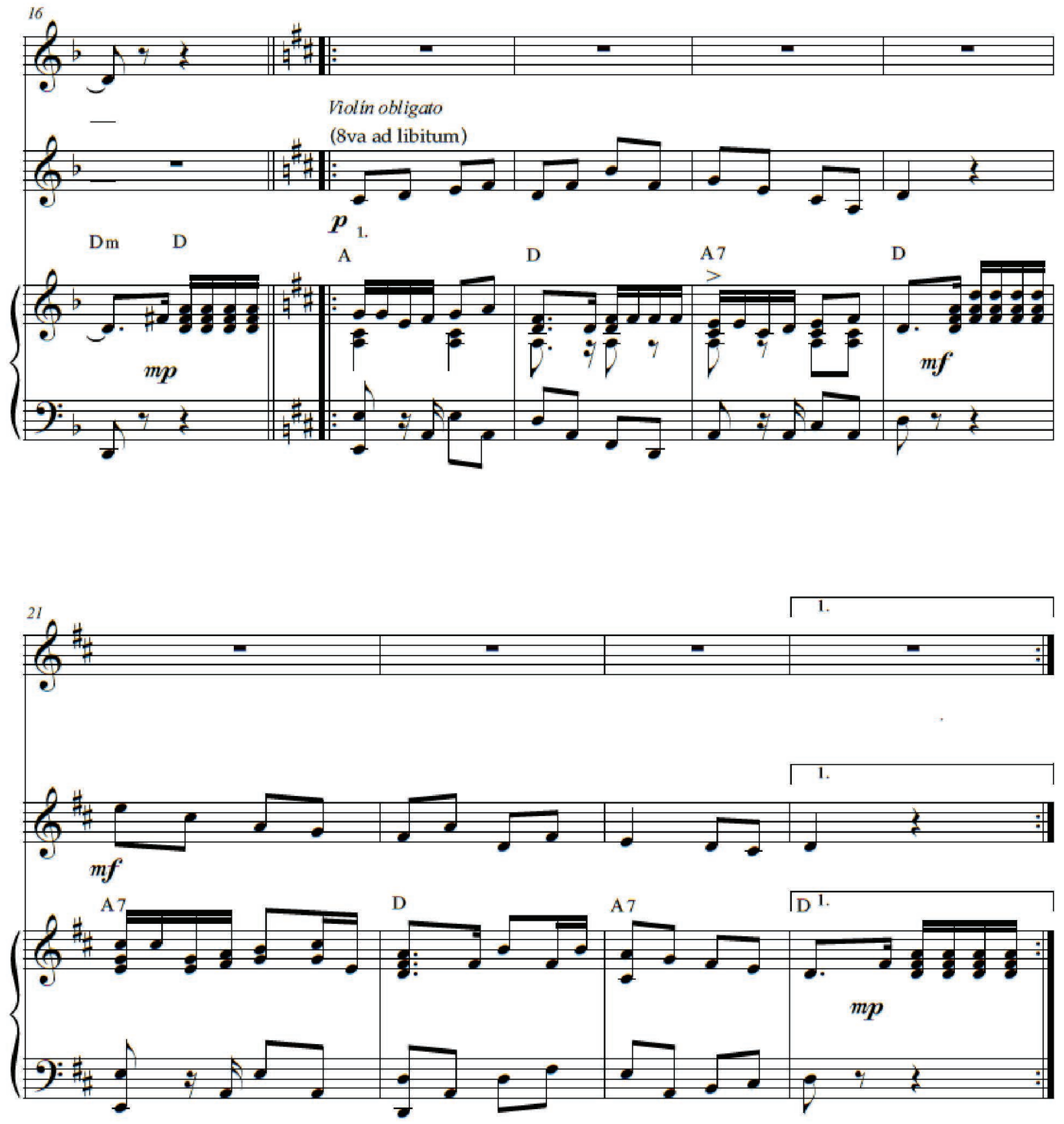

1. pizz ad libitum

Caña dulce 

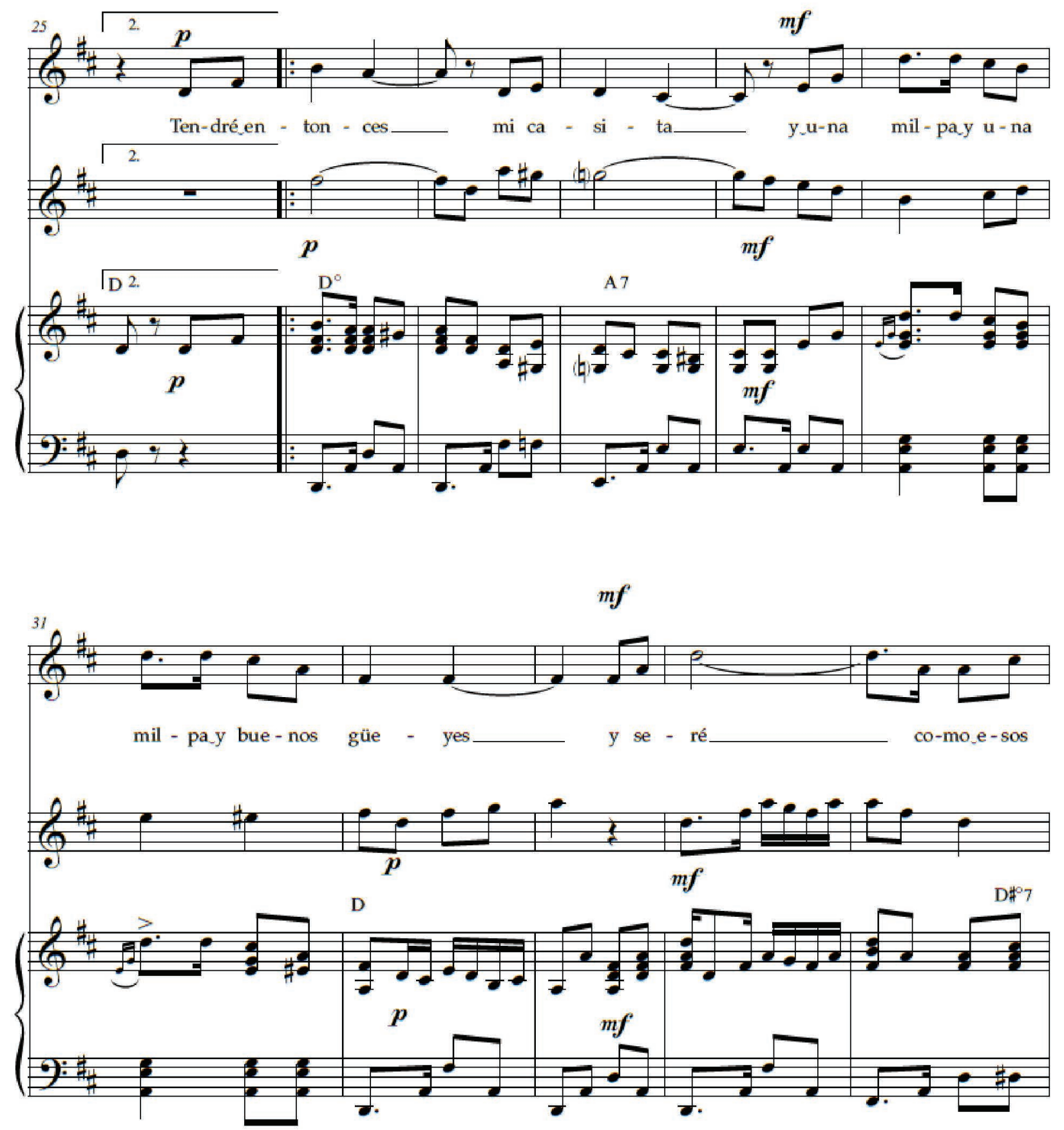

Caña dulce 


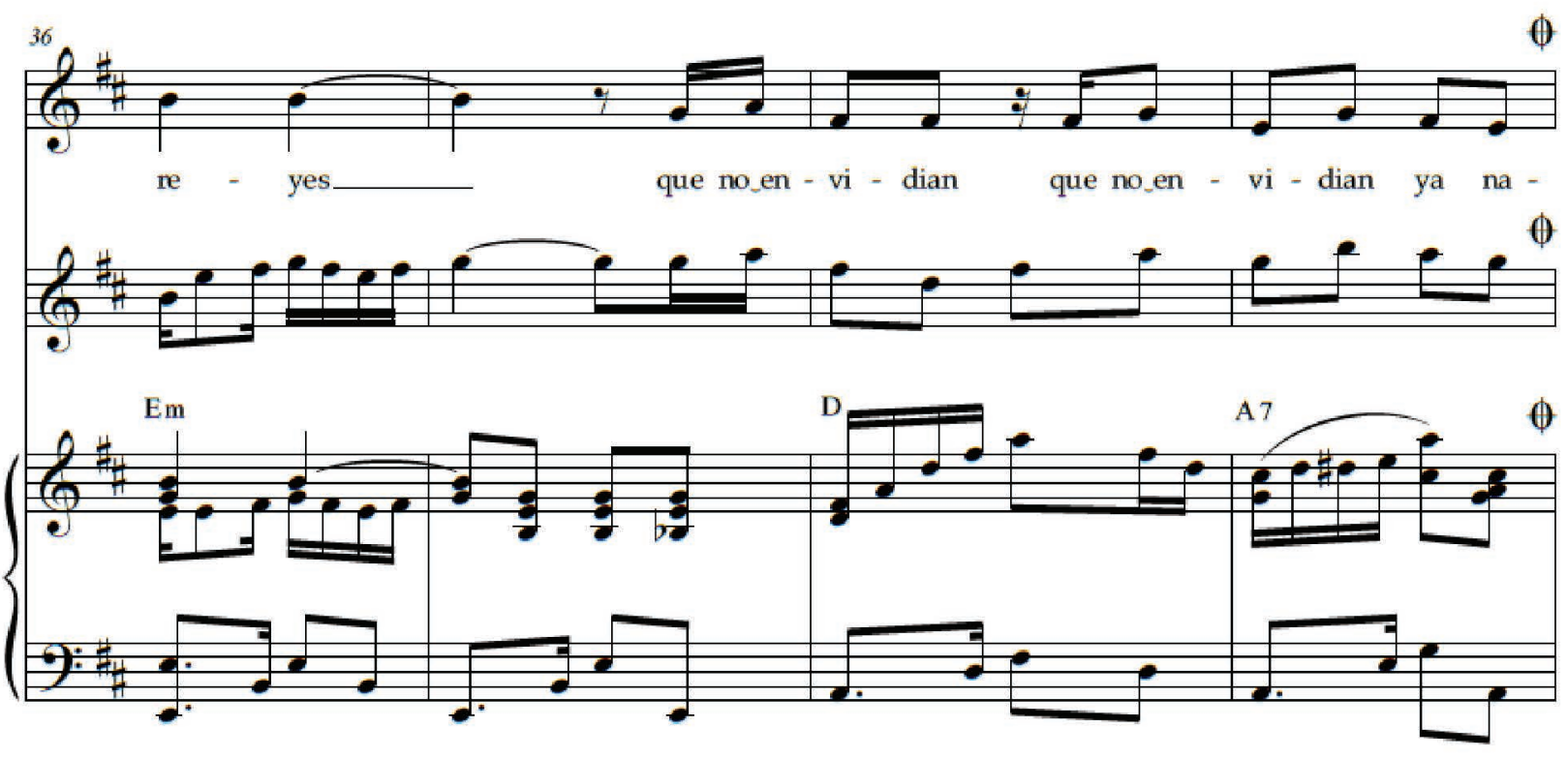

D.C. senza replica $\phi$

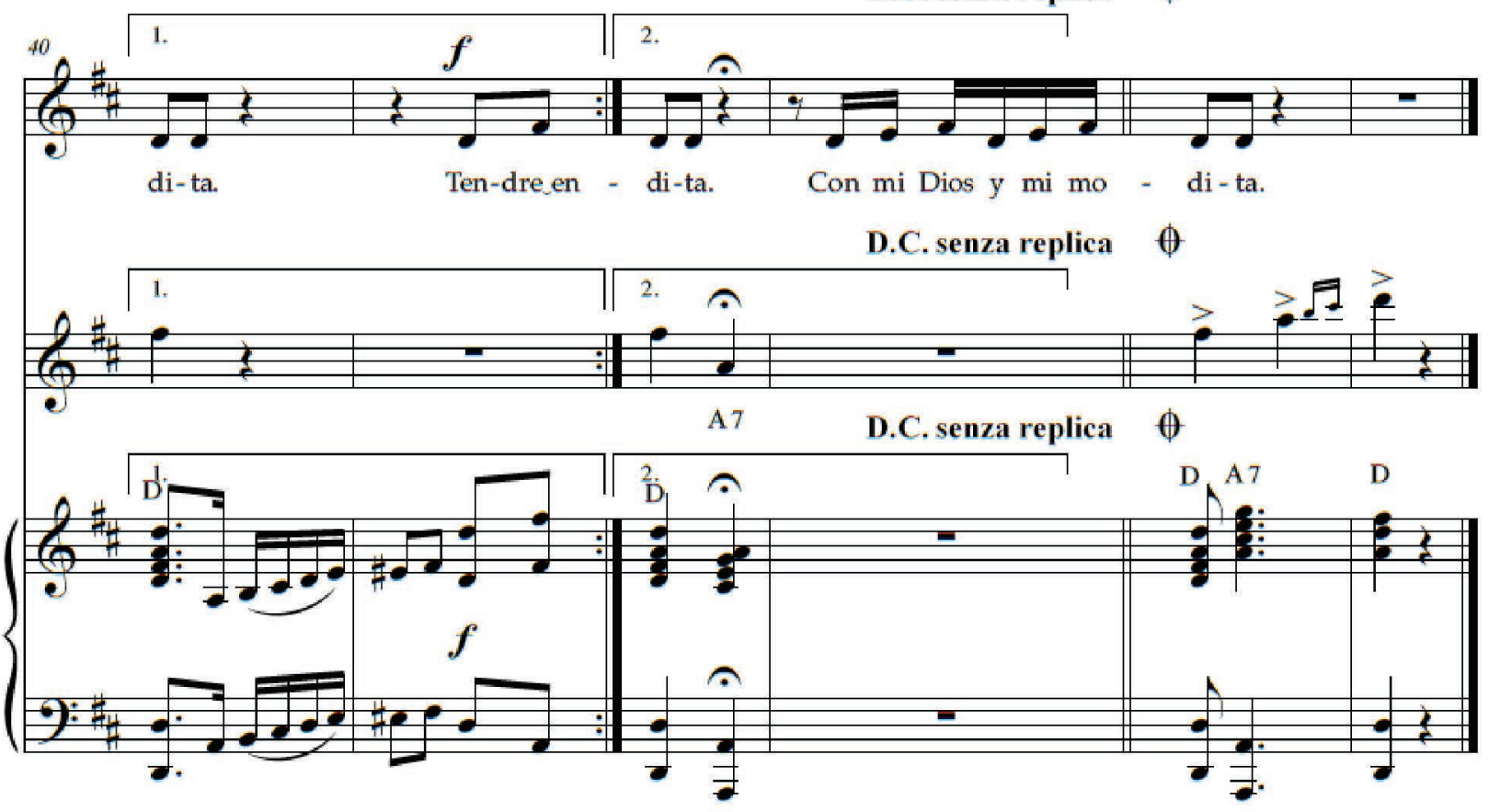

Caña dulce 